\title{
In situ structuring of virioplankton through bacterial exoenzymatic activity: interaction with phytoplankton
}

\author{
P. Ory ${ }^{1}$, S. Palesse ${ }^{1}$, D. Delmas ${ }^{2}$, H. Montanié ${ }^{1, *}$ \\ ${ }^{1}$ Littoral, Environnement et SociétéS (LIENSs) Université de La Rochelle UMR 6250 CNRS-ULR, \\ 17042 La Rochelle Cedex, France \\ ${ }^{2}$ Laboratoire Dyneco-IFREMER, Technopôle de Brest-Iroise, BP 70, 29280 Plouzané, France
}

\begin{abstract}
The abundance and composition of microbial communities were investigated during 2007 in Marennes Oléron Bay (France) in order to characterize the biological relationships governing the planktonic food web. Compared to the results of previous years, there was a lower abundance and a lower magnitude of variations in autotrophic and heterotrophic microbial entities in 2007. Using a Spearman rank correlation analysis, a significant link for biological abundance was only noted between bacteria and ciliates. However, an interesting relationship was highlighted between chlorophyll $a$ and bacterial aminopeptidase and $\beta$-glucosidase exoenzymatic activities. Two characteristic periods of virus-bacteria uncoupling were observed in spring and autumn 2007. Using multivariate analysis, the clustering of monthly viral community structures (defined by RAPD-fingerprinting) was related to bacterial proteolysis activity and secondarily to flagellates. Spring and autumn were characterized by phytoplanktonic blooms of large $(>10 \mu \mathrm{m})$ and small cells $(<10 \mu \mathrm{m})$, respectively, during the virus-bacteria uncoupling phases. High predation by flagellates in the autumn, during a period of microbial food web activity, involved the highest viral fingerprint richness, inferring a top-down control in driving the number of virus-host systems. We discuss the proteolysis level as a descriptor in structuring viral assemblages and argue that changes in the quantity and quality of DOM may bridge phytoplankton to bacteria and reflect changes in phytoplankton composition.
\end{abstract}

KEY WORDS: Virus · Bacteria $\cdot$ Phytoplankton $\cdot$ Diversity $\cdot$ Aminopeptidase

\section{INTRODUCTION}

Bacteria and viruses are the most abundant biological entities in the marine microbial world (Borsheim et al. 1990, Hennes \& Suttle 1995). Producers such as phytoplankton and bacterioplankton are involved in trade-offs between (1) bottom-up and (2) top-down mechanisms regulating both abundance and community structure (Winter et al. 2010).

(1) In terms of abundance and community structure, bacterioplankton are particularly dependent on the quantity and quality of inorganic nutrients and organic matter, which may impact their metabolism, growth and community structure (Kirchman et al. 2004, Teira et al. 2010). Around $30 \%$ of organic matter in the ocean is composed of high molecular weight compounds (HMWC, >600 Da), and their uptake by bacteria is only possible after extracellular hydrolysis (Karner \& Herndl 1992, Nagata 2008). The major components of this organic matter being proteins and carbohydrates, the ability of a species to produce peptidase and glucosidase enzymatic activities influences its growth and acts as a structuring factor of the community (Van Wambeke et al. 2009).

(2) The development of bacterial populations is also controlled by predators, namely grazers such as unpigmented nanoflagellates and parasites such as viruses (Winter et al. 2010). With regards to their abundance 
and grazing efficiency, unpigmented nanoflagellates are able to sustain their growth with bacteria and can potentially control bacterial abundance (Berglund et al. 2005). The virus-mediated mortality of bacteria is comparable to that of grazer-mediated mortality (Fuhrman \& Noble 1995, Fuhrman 1999). However, while grazing leads to carbon transfer to higher trophic levels, except with sloppy feeding (Cherrier et al. 1996), viral lysis enhances the microbial loop through the viral shunt (Wilhelm \& Suttle 1999), where the release of dissolved organic matter (DOM) which is available for bacteria favors the recycling of organic and inorganic nutrients (Suttle 2007). Indeed, without the microbial loop activities of prokaryotes, which transform nutrients into biomass, DOM would not be transferred to higher trophic levels. Thus, the viral shunt may act as a lubricant for the microbial loop short term and could contribute actively to biochemical cycles long term (Middelboe \& Lyck 2002, Winget et al. 2005, Weinbauer et al. 2009).

From a qualitative point of view, prey-predator or parasite-host trophic interactions between microbial entities (prey-predator or parasite-host; Miki \& Jacquet 2008) induce changes in the structure of each microbial assemblage: the size-selective grazing of nanoflagellates enhances the development of either small or large bacteria (Jürgens \& Matz 2002) and impacts the morphometric (occurrence of resistant morphotypes) and taxonomic structures of bacterial communities (Suzuki 1999, Langenheder \& Jürgens 2001). Viruses, which have a higher specificity for their host, induce modifications in the composition of the bacterial community as described in the 'killing the winner' theory (Thingstad 2000), which has been confirmed with experimental investigations and field data (Fuhrman \& Schwalbach 2003, Hewson et al. 2003, Weinbauer \& Rassoulzadegan 2003, Schwalbach et al. 2004, Winter et al. 2004b, Bouvier \& Del Giorgio 2007), as reviewed and discussed in Winter et al. (2010). Hence, viral lysis of the abundant host group would favor rare groups and help maintain bacterial specific richness.

Viral lysis can also indirectly affect bacterial community composition: lysis, releasing new substrates, modifies DOM composition and enhances, via feedback, the growth of competitive bacterial species (Middelboe et al. 2003). Bacterial diversity and viral abundance are either positively or negatively linked (Winter et al. 2004a, Auguet et al. 2008). The presence of grazers can also stimulate viral multiplication in the bacterioplankton through a cascading effect from grazing-mediated resource enrichment (Šimek et al. 1997, Jürgens et al. 1999, Pradeep Ram \& Sime-Ngando 2008).

Bottom-up and top-down controls act together in shaping virus-host system (VHS) diversity. As a result of trade-offs between competition and defense specialists (Winter et al. 2010), the number of simultaneously co-existing VHS are selected by top-down mechanisms (grazers, viruses), being more or less based on host-specificity, while bottom-up mechanisms (resources) drive the community structure of the VHS (Sandaa et al. 2009). Indeed, changes in nutritive conditions may affect the selection for dominant members of the bacterial community, and thus viral and bacterial community structures could change in parallel. First, bacterial phylotypes that are good competitors for nutrients would be lysed and then the virus-resistant phylotypes would compete with each other. However, top-down and bottom-up controls are linked because viruses and grazers could also have a strong indirect bottom-up effect by modifying the quality and quantity of nutritive resources (Sandaa et al. 2009, Miki \& Jacquet 2010).

However, aside from bacterioplankton, virioplankton and grazers, phytoplankton act not only as a provider of DOM but also as a competitor for inorganic nutrients (Kirchman 1994, Rivkin \& Anderson 1997, Joint et al. 2002). Consequently, phytoplankton drive the development and structuring of other microbial entities and their interactions. Their link with viruses through viral infection has been clearly identified, particularly during bloom periods (Bratbak et al. 1993, Brussaard et al. 1995, Agusti et al. 1998), with from 10 to $50 \%$ of algal cells visibly infected at the end of a specific bloom (Gastrich et al. 2004). The release of phytoplankton cell content by viral lysis would provide enough DOM to meet the carbon demand of bacteria in the case of a phytoplankton decline (59 to $70 \%$; Brussaard et al. 2005). The relationship between phytoplankton and bacterial biomass or production has not been as clearly established in field studies, probably due to the uncoupling of production periods relying on: (1) a consumption of allochthonous dissolved organic matter by bacteria, (2) a time lag between DOM exudation by phytoplankton and its subsequent consumption by bacteria, and (3) a nutrient limitation of consumption (Alonso-Saez et al. 2008).

Exoenzymatic activities have been hypothesized to be indicators of the bacterial consumption of HMWC and thus could also characterize peaks of primary production. This is supported by the following arguments: (1) the proteolysis:glycolysis ratio is higher during productive periods, with low specific $\beta$-glucosidase activity; (2) when phytoplanktonic cells collapse, the large amount of polysaccharides released induces the synthesis of $\beta$-glucosidase; (3) during periods of nutrient limitation, more HMWC and DOM may be released (Alonso-Saez et al. 2008). However, exoenzymatic activities may also depend upon an influx of allochthonous $\mathrm{C}$ compounds (from river discharge or the resus- 
pension of benthic matter). These could be induced by the release of viral lysis products from bacteria, and activity changes could reflect shifts in bacterial community composition (Martinez et al. 1996).

In Marennes Oléron Bay (France), previous studies on pelagic microbial organisms and the control of their dynamics highlighted a link between virus abundance and chlorophyll a (chl a) concentration (Ory et al. 2010) and described chl a biomass as a significant factor driving the variability of bacterial activities (secondary production and exoenzymatic activities; Auguet et al. 2005). By analyzing a new dataset collected during a 1 yr survey in the mesotrophic coastal ecosystem of the Marennes Oléron Bay (MOB), the present study addresses viral assemblage structuring. The objectives were: (1) to assess the structure of the virioplankton assemblage by RAPD-PCR (randomly amplified polymorphism DNA-polymerase chain reaction) analysis and (2) to relate changes in viral assemblage with changes in bacterial community composition, together with the dynamics of other microbial entities (grazers and phytoplankton) and environmental parameters, notably the potential consumption of high molecular weight-DOM, by measuring bacterial exoenzymatic activity.

\section{MATERIALS AND METHODS}

Study area. MOB is located in the north of the Bay of Biscay $\left(46^{\circ} 00^{\prime} \mathrm{N}, 1^{\circ} 10^{\prime} \mathrm{W}\right)$, along the French Atlantic coast. The bay (surface area $=175 \mathrm{~km}^{2}$; mean depth $=$ $8.6 \mathrm{~m}$ ) is composed of $60 \%$ intertidal mudflats and exposed to a macrotidal system (amplitude $=2$ to $6 \mathrm{~m}$ ). MOB is open to the Atlantic Ocean through a broad northern pass (Pertuis d'Antioche) and a narrowed southern pass (Pertuis de Maumusson). The importance of tidal exchanges through the northern pass results in a northward to southward circulation of oceanic waters from the Bay of Biscay (water residence time $=11 \mathrm{~d}$ ). The bay is polyhaline to euryhaline (mean salinity = $30.9 \pm 4.2 \%$; Struski 2005), and freshwater arrives mainly from the Charente River $(90 \%)$, with annual mean runoffs of $100 \mathrm{~m}^{3} \mathrm{~s}^{-1}$ (data: DDE-Charente Maritime/HYDRO-MEDD/DE; http://hydro.eaufrance.fr).

Sampling strategy and field measurements. Samplings were performed monthly from January to December 2007 at high tide, during periods of medium tidal coefficient $(\approx 60)$ at 1 northern station located in the external part of the Charente River estuary $\left(45^{\circ} 59^{\prime} 16.7^{\prime \prime} \mathrm{N}, 1^{\circ} 10^{\prime} 0.7^{\prime \prime} \mathrm{W}\right.$, 'Stn E' previously monitored by Auguet et al. [2005] and by Ory et al. [2010]); in February, sampling was performed closer to the mouth of the estuary $\left(45^{\circ} 59^{\prime} 5.06^{\prime \prime} \mathrm{N}, 1^{\circ} 06^{\prime} 32^{\prime \prime} \mathrm{W}\right)$, because bad weather prohibited sampling at Stn E.
Samples were collected near the surface, at $<1 \mathrm{~m}$ depth. Subsamples for microorganism counts (except ciliates) were fixed on board according to the specificity of each organism. The remainder was kept in 81 polypropylene dark bottles for $<2 \mathrm{~h}$ at the in situ temperature until laboratory analyses were performed. Physical parameters (temperature, salinity and $\mathrm{pH}$ ) were recorded on board (YSI 6600EDS-M multiparameter probe).

Zooplankton were collected using a $200 \mu \mathrm{m}$ WP-2 net equipped with a digital flowmeter (Model 2030, General Oceanics). The catch was fixed in formaldehyde (4\% final concentration).

Physical and chemical parameters. Mineral and organic seston were assessed by filtering 200 to $500 \mathrm{ml}$ of water, depending on the turbidity, under gentle vacuum pressure (GF/F Whatman filters; Auguet et al. 2005).

Dissolved inorganic nutrients (phosphate $\left[\mathrm{PO}_{4}\right]$, urea, ammonium $\left[\mathrm{NH}_{4}\right]$, nitrite $\left[\mathrm{NO}_{2}\right]$ and nitrate $\left.\left[\mathrm{NO}_{3}\right]\right)$ were filtered $(20 \mathrm{ml}, \mathrm{GF} / \mathrm{F}$ Whatman) into a glass flask and stored for 2 to $3 \mathrm{wk}$ at $-20^{\circ} \mathrm{C}$. Analyses were performed using an autoanalyser (Skalar; Strickland \& Parsons 1972).

Biological parameters. Chlorophyll a and pheopigment: Water samples of $200 \mathrm{ml}$ were vacuum filtered onto $25 \mathrm{~mm}$ Whatman GF/F filters. The filters were stored for $<1 \mathrm{mo}$ at $-20^{\circ} \mathrm{C}$ until assessment by extraction with $90 \%$ acetone (overnight at $4{ }^{\circ} \mathrm{C}$, under agitation) and fluorimetric analysis (Turner, TD 700) (Lorenzen 1966).

Microbiological abundance: Triplicate subsamples for viral and bacterial abundance assessments were fixed on board with $0.02 \mu \mathrm{m}$ filtered formaldehyde $(2 \%$ final concentration) and stored for $<24 \mathrm{~h}$ at $4^{\circ} \mathrm{C}$. Samples were enumerated by epifluorescence microscopy (Noble \& Fuhrman 1998) as follows: $2 \mathrm{ml}$ of MilliQ water-diluted samples (50-fold on average for accurate microscopic observations) were retained on $0.02 \mu \mathrm{m}$ silicate membranes (Anodisc) followed by SYBR Green I staining (Invitrogen-Molecular Probes) for $30 \mathrm{~min}$, then mounted on a glass slide and stored at $-20^{\circ} \mathrm{C}$ for from 1 to $2 \mathrm{~d}$ until bacteria and viruses could be counted under blue excitation at 1000× magnification on a Zeiss Axioskop 2 Mot Plus microscope (100× Plan APO oil objective).

Small phytoplanktonic cells were quantified by flow cytometry using a FACSCalibur flow cytometer (size $<10 \mu \mathrm{m}$ ) from samples flash-freezed and stored at $-80^{\circ} \mathrm{C}$ (for $<1 \mathrm{yr}$ ). Synechococcus were distinguished from photosynthetic eukaryotes by their orange fluorescence; picoeukaryotes and nanoeukaryotes produced a red autofluorescence (Joux et al. 2005).

For nanoflagellates, duplicate samples of seawater were fixed on board ( $1 \%$ paraformaldehyde final con- 
centration) and stored at $4^{\circ} \mathrm{C}$ for $<1 \mathrm{wk}$. Samples were filtered through $0.8 \mu \mathrm{m}$ black polycarbonate membranes (Nuclepore); the cells were stained with DAPI (Porter \& Feig 1980) and frozen at $-20^{\circ} \mathrm{C}$ for from 1 to 2 wk until counting under ultraviolet excitation. Counting was performed at $1000 \times$ magnification on a Zeiss Axioskop 2 Mot Plus microscope (100× Plan APO oil objective).

For ciliates, $1 \mathrm{l}$ seawater was sampled and stored for $6 \mathrm{~h}$ in the dark at the in situ temperature in order to decant the suspended matter. Thereafter, the top $850 \mathrm{ml}$ were siphoned off, gently mixed, and a subsample was fixed in alkaline lugol ( $1 \%$ final concentration) and stored at $4{ }^{\circ} \mathrm{C}$ for $<1 \mathrm{mo}$. Ciliates were counted in Utermöhl settling chambers, after decantation of from 20 to $50 \mathrm{ml}$, under white light at $630 \times$ magnification on a Leica DMIRB microscope (630× Fluotar objective). A sample of microphytoplankton was directly fixed with a combination of formaldehyde (1\% final concentration) and alkalin lugol (1\% final concentration), and from 10 to $20 \mathrm{ml}$ subsamples were directly decanted in Utermöhl settling chambers before counting at $400 \times$ magnification on a Nikon diaphot microscope (200x APO Plan objective). Mesozooplankton samples were analyzed with a binocular loupe (Sautour \& Castel 1993).

Bacterial activity: Leucine aminopeptidase (AMPase) and $\beta$-glucosidase ( $\beta$-GLCase) activities were measured using L-leucine-7-amino-4-methylcoumarin hydrochloride (Leu-MCA, Sigma) and 4-methylumbelliferyl $\beta$-D-glucopyranoside (MUF-Glc, Sigma) as a protein and carbohydrate model substrate, according to Hoppe (1993). Different substrate concentrations were added to aliquot fractions of sampled water to determine the enzymatic kinetics as follows: 10 final concentrations, ranging between 1.9 and $1000 \mu \mathrm{M}$ for AMPase and 7 final concentrations ranging between 0.39 and $100 \mu \mathrm{M}$ for $\beta$-GLCase.

Incubations were performed in the dark and at the in situ temperature for 1 to 15 and 3 to $15 \mathrm{~h}$ for the Leu-MCA and MUF-Glc assays, respectively, depending on the sea temperature and consequently on the level of enzymatic activity. Sodiumdodecyl sulfate (SDS $1 \%$ final concentration) and $\mathrm{NH}_{4}$-glycin buffer $(\mathrm{pH}$ 10.5) were added to stop the reactions of the AMPase and $\beta$-GLCase activity assays (Chróst 1992, Delmas \& Garet 1995). Negative controls were performed for each substrate concentration by addition of an inhibitor (SDS or $\mathrm{NH}_{4}$-glycin, respectively) at the beginning of the incubation. Samples were immediately frozen at $-20^{\circ} \mathrm{C}$ and stored for 1 to 2 wk before the fluorescence reading was performed (Kontron SFM 25 spectrofluorometer: excitation, 380 and $364 \mathrm{~nm}$, emission 440 and $450 \mathrm{~nm}$ for Leu-MCA and MUF-Glc, respectively). Solutions of 7-amino- 4-methylcoumarin (AMC, Sigma) (20 to $2000 \mathrm{nM}$ ) and 4-methylumbelliferon (MUF, Sigma) (2 to 2000 $\mathrm{nM}$ ) were used as calibration standards. The enzymatic activity, expressed as the maximum of potential activity $\left(V_{\max }, \mathrm{nmol} \mathrm{l^{-1 }} \mathrm{h}^{-1}\right)$, was estimated through non-linear regression (Hyper32 software, JS Easterby). The activity of AMPase is considered to be an indicator of bacterial production in MOB based on the significant relationship shown between AMPase $\left(V_{\max }\right)$ and bacterial production (BP), which was assessed using tritiated thymidine incorporation during a previous survey (2002 to 2003, same sampling station): $\log \mathrm{BP}=0.72 \log \mathrm{AMPase}-1.14, \mathrm{r}^{2}=0.67, \mathrm{n}=$ $10, \mathrm{p}=0.003$ (D. Delmas, unpubl. data). Therefore, the ratio of AMPase: $\beta$-GLCase $V_{\max }$ could be calculated and considered to be the expression of the nutritional quality indicator for each substrate (Polymenakou et al. 2005).

Bacterial community composition: Bacterial community composition was determined by the in situ fluorescent hybridization method (DeLong et al. 1989) using 8 Cy-3 labeled probes (MWG-Biotech): Eub 338 I, II and III, specific for Eubacteria, Pla5a for Planctomycetes, CF319a for the Cytophaga-Flavobacterium cluster (CFB), Alf1b for Alphaproteobacteria, Bet43a for Betaproteobacteria, Gam42a for Gammaproteobacteria, and a non-specific control probe (Amann et al. 1995, Bouvier \& Del Giorgio 2007). Archaea was detected using Arch915 (Amann et al. 1995). Samples fixed in paraformaldehyde ( $2 \%$ final concentration) were kept overnight at $4^{\circ} \mathrm{C}$ before being stored at $-20^{\circ} \mathrm{C}$. Thawed subsamples were filtered onto $0.2 \mu \mathrm{m}$ polycarbonate membranes (Whatman), rinsed with $0.2 \mu \mathrm{m}$ filtered Milli-Q water, air-dried and stored

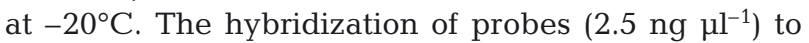
bacteria was carried out for $4.5 \mathrm{~h}$ at $46^{\circ} \mathrm{C}$ before the membrane was washed at $48^{\circ} \mathrm{C}$ in a pre-warmed $\left(48^{\circ} \mathrm{C}\right)$ wash solution for $15 \mathrm{~min}(102 \mathrm{mM} \mathrm{NaCl}$ [except for CFB: $80 \mathrm{mM} \mathrm{NaCl}$ ]; $20 \mathrm{mM}$ Tris, $\mathrm{pH}$ 8; 5 mM EDTA, $\mathrm{pH} 8 ; 0.01 \%$ SDS). The membrane was then rinsed, first with $0.2 \mu \mathrm{m}$ filtered Milli-Q water, then with $80 \%$ ethanol, and then air-dried. Bacterial cells were counter-stained with DAPI $\left(0.25 \mu \mathrm{gl}^{-1}\right)$ in a mounting solution of Citifluor (Biovalley) and Vectashield (Ablys) mixed to a ratio of 4:1. A minimum of 250 cells were enumerated using an epifluorescence microscope (Axioskop, Zeiss) equipped with Cy3 (blue) and DAPI (UV) filters.

Viral community structure (RAPD-PCR fingerprinting). Approximately 121 water samples were filtered using a peristaltic pump through a succession of nylon fiber sieves (from 250 down to $25 \mu \mathrm{m}$ ) and sequentially though 2 membranes barriers ( 3 and $0.8 \mu \mathrm{m}$ pore size cellulose acetate filters, $142 \mathrm{~mm}$ diameter; Sartorius) to remove sediment particles and large microorganisms; 
a final $0.2 \mu \mathrm{m}$ filtration (cellulose acetate membrane, $142 \mathrm{~mm}$; Sartorius) resulted in a bacteria-free sample (Auguet et al. 2008). Based on Suttle et al. (1991) and using the protocol of Auguet et al. (2008), viruses were then concentrated by a tangential ultrafiltration through a $30 \mathrm{kDa}$ polysulfon cartridge (Ultraslice support, Sartorius) into 200 to $300 \mathrm{ml}$. After storage at $-20^{\circ} \mathrm{C}$ for $1 \mathrm{yr}$ for the oldest samples, viral concentration was achieved by ultracentrifugation at $150000 \times g$ at $\mathrm{r}_{\max }$ for $3.5 \mathrm{~h}$ at $4^{\circ} \mathrm{C}$ (LE 70 Beckmann ultracentrifuge 28.1 rotor). The pellet of viral concentrate was resuspended in $100 \mu \mathrm{l}$ of $\mathrm{SM}$ buffer $(0.1 \mathrm{M} \mathrm{NaCl}, 8 \mathrm{mM}$ $\mathrm{MgSO}_{4} \mathrm{H}_{2} \mathrm{O}, 50 \mathrm{mM}$ Tris- $\mathrm{HCl}, 0.005 \%$ [w/v] glycerol) and stored at $4^{\circ} \mathrm{C}$.

To examine the potential presence of non-viral DNA in viral concentrate samples, DNase treatment tests were performed with the April 2007 and November 2007 samples and analyzed with RAPD-PCR amplification. Preliminary, optimization of the DNAse test was performed with a Lambda genome (as a positive genome control) and a T2 virus suspension (as a purified virion target), with the aim of optimizing buffer choice (hot-start PCR buffer [Qiagen] versus RQ1 RNase-free DNase buffer) and the number of DNase units used (1 or $5 \mathrm{U}$; Promega).

DNase reaction mixtures contained 1 or $5 \mathrm{U}$ RQ1 RNase-free DNase, 1× RQ1 RNase-free DNase buffer or $1 \times$ HotStart Taq polymerase reaction buffer, $1 \mu \mathrm{l}$ Lambda DNA $(0.46 \mu \mathrm{g})$ or T2 virus suspension or the monthly samples (viral titer: $1 \times 10^{7}$ viruses $\mathrm{ml}^{-1}$ ) and nuclease-free water for a final volume of $20 \mu \mathrm{l}$. The DNase reaction was performed over $30 \mathrm{~min}$ at $37^{\circ} \mathrm{C}$ and stopped by heating at $75^{\circ} \mathrm{C}$ for $15 \mathrm{~min}$. One microliter of each DNase reaction was used as template DNA for RAPD-PCR amplification.

Prior to RAPD-PCR, virions need to be decapsidated by heating at $60^{\circ} \mathrm{C}$ for $10 \mathrm{~min}$ and rapidly cooling to $4^{\circ} \mathrm{C}$ until amplification (Fuhrman et al. 2002). The efficiency of decapsidation was also tested with a DNase treatment performed on both encapsidated and decapsidated T2 virions. Decapsidation efficiency was confirmed with the hydrolysis of DNA of decapsidated T2 as opposed to encapsidated T2 (positive control). RAPD-PCR was then performed with, as template DNA, results from DNase and decapsidation tests, monthly samples DNase treated and the 12 monthly samples.

Adapted from Winget \& Wommack (2008), amplification was performed with 2 primers (OPA13 [5'-CAG CAC CCA-3'] and CRA22 [5'-CCG CAG CCA-3'], MWG-Biotech Inc.) and using $10 \mu \mathrm{M}$ dNTP, $4 \mu \mathrm{M}$ primer (acting forwardly and reversely), 1× Taq polymerase reaction buffer, 2 U Taq polymerase (HotStart, Qiagen) and $1 \mu \mathrm{l}$ viral concentrate compared to a constant viral titer $\left(2 \times 10^{6}\right.$ viruses $)$ with CRA22. The PCR was carried out as follows: (1) $94^{\circ} \mathrm{C}$ for $15 \mathrm{~min}$, (2) $35^{\circ} \mathrm{C}$ for $3 \mathrm{~min}$, (3) $72^{\circ} \mathrm{C}$ for $1 \mathrm{~min}$, (4) $94^{\circ} \mathrm{C}$ for $30 \mathrm{~s}$, (5) repeat steps 2 to 4 for 30 cycles, (6) $72^{\circ} \mathrm{C}$ for $10 \mathrm{~min}$, and (7) hold at $10^{\circ} \mathrm{C}$ (PTC-100, MJ Research). The PCR products were resolved by $2 \%$ MetaPhor agarose gel (Lonza) electrophoresis in $0.5 \times$ TBE buffer (TrisBorate-EDTA) at $4 \mathrm{~V} \mathrm{~cm}^{-1}$, stained with Gel Star (Lonza) and visualized with Gel Doc 2000 (Bio-Rad).

Banding patterns were analyzed with the Diversity Database program (Version 2.2.0, Bio-Rad) which provided banding pattern alignment analyses, qualitative analyses of the number of bands for each sample (presence versus absence) and quantitative analyses using densitometry. The total number of observed bands, the RAPD-PCR amplicons, was defined as the fingerprint richness. For each month, triplicates of RAPD-PCR amplifications and gel migrations were used to test the reproducibility of the RAPD-PCR amplifications.

Statistical analyses. Regression and correlation analyses (Spearman rank correlation, $\rho$ ) were performed with Xlstat (the correlation significance was tested using a 2-tailed $t$-test). RAPD-PCR banding patterns were first compared with the 'unweighted pair group method with arithmetic mean' in the Diversity Database program to assess the reproducibility of RAPD-PCR banding patterns and the effect of DNase treatment. Second, viral diversity data were standardized for 'species' in order to reduce the dominant contribution of abundant species in a Bray-Curtis similarity matrix and then normalized by fourth-root transformation. Environmental data were log-transformed under draftsman plot information before being represented in a similarity matrix (Euclidean distance). Nonmetric multi-dimensional scaling (MDS) ordination was performed from both similarity matrices (viral diversity and environmental data). Non-parametric analysis of similarity (ANOSIM) tested the robustness of MDS clustering (good if $\mathrm{R}>0.6$ ). Third, attempts to link viral assemblages to environmental data were performed to find the best explanatory variables of the observed RAPD-PCR banding pattern. The link was carried out using the BEST procedure in the Primer 6 software (Clarke \& Ainsworth 1993, Clarke \& Gorley 2006). This procedure combined the BIO-ENV and Stepwise procedures and consisted in performing a Spearman rank correlation analysis based on the computation between the elements of 2 triangular matrices: a resemblance matrix of viral assemblage (Bray-Curtis distance) and an explanatory data matrix of environmental data (Euclidean distance). The BIO-ENV procedure selects a subset of environmental data to maximize the matching Spearman rank correlation ( $\rho$ coefficient) with the 2 assemblage similarities. It identifies numerically an environmental data subset sufficient to explain all the biotic 
structure of the viral assemblage. A global BEST match permutation test assesses the significance of rho. A linkage tree was then applied with the LINKTREE algorithm, corresponding to binary dividing clustering of the monthly viral assemblage structures. Each cluster was chosen to maximize the ANOSIM R statistic and was interpreted in terms of inequalities in explicative environmental variables. An absolute measure of cluster differences is given by the $\mathrm{B} \%$ value, where low values correspond to closer samples on the MDS plot. In fine, this LINKTREE procedure was validated by the similarity profile test (SIMPROF test), a permutation test used to demonstrate the significant evidence of an internal group structure. In our study case, this complete procedure selected the optimum combination in an 'environmental' variable subset, maximizing rankcorrelation ( $\rho$ ) between the viral assemblage structure and environmental matrices. The 'environmental matrix' was composed of 19 biotic and abiotic variables, and we chose to test the best combination of 1 to 9 out of the 19 available.

\section{RESULTS}

\section{Physical and chemical parameters}

Water temperature and salinity data are presented in Table 1 together with measurements of inorganic nutrients (for details see Fig. S1 in the supplement at www.int-res.com/articles/suppl/a064p233_supp.pdf): $\mathrm{NO}_{3}$ remained above $20 \mu \mathrm{mol} \mathrm{l} \mathrm{l}^{-1}$ most of the year, except in the autumn, and peaked at $115 \mu \mathrm{mol} \mathrm{l}^{-1}$ in February (riverine sampling) and at $67 \mu \mathrm{mol} \mathrm{l}^{-1}$ in March. $\mathrm{PO}_{4}$ fell below $0.5 \mu \mathrm{mol} \mathrm{l}^{-1}$ from February until the end of June, while it peaked towards the end of August and reached its highest value $\left(2.0 \mu \mathrm{mol} \mathrm{l}^{-1}\right)$ in November. Seston was composed on average of $20 \%$ organic and $80 \%$ inorganic matter. With an annual mean of $18.7 \pm 13.4 \mathrm{mg} \mathrm{l}^{-1}$, it peaked twice, in February (53.8 $\left.\mathrm{mg} \mathrm{l}^{-1}\right)$ and July $\left(27.5 \mathrm{mg} \mathrm{l}^{-1}\right)$. The annual mean

Table 1. Mean, minima and maxima of abiotic and chlorophyll a parameters, with dates, at Marennes Oleron Bay during the year 2007. Runoff data were supplied by the DDE-Charente Maritime/HYDRO-MEDD/DE for the Charente River

\begin{tabular}{|lccc|}
\hline & Annual mean & Min/Date & Max/Date \\
\hline Water temperature $\left({ }^{\circ} \mathrm{C}\right)$ & 14.22 & $6 / 19 \mathrm{Dec}$ & $20.5 / 24 \mathrm{May}$ \\
Salinity $(\mathrm{PSU})$ & 31.25 & $23.2 / 28 \mathrm{Feb}$ & $34.3 / 22 \mathrm{Oct} \&$ 20 Nov \\
Nitrate $(\mu \mathrm{M})$ & 41.71 & $8.10 / 4 \mathrm{Oct}$ & $115.05 / 28 \mathrm{Feb}$ \\
Phosphate $(\mu \mathrm{M})$ & 0.77 & $0.07 / 24 \mathrm{Apr}$ & $2.01 / 20 \mathrm{Nov}$ \\
Chlorophyll $\mathrm{a}\left(\mathrm{g} \mathrm{l}^{-1}\right)$ & 2.21 & $0.5 / 30 \mathrm{Jan}$ & $4.48 / 11 \mathrm{Jul}$ \\
Total seston $\left(\mathrm{mg} \mathrm{l}^{-1}\right)$ & 18.66 & $8.93 / 4 \mathrm{Oct}$ & $53.76 / 28 \mathrm{Feb}$ \\
Charente runoff $\left(\mathrm{m}^{3} \mathrm{~s}^{-1}\right)$ & 77.42 & $17.2 / 22 \mathrm{Oct}$ & $252 / 15 \mathrm{Mar}$ \\
\hline
\end{tabular}

chl a concentration was $2.2 \pm 1.2 \mu \mathrm{g} \mathrm{l} \mathrm{l}^{-1}$. Three major peaks occurred, in February, April and July $(2.1,3.5$ and $4.5 \mu \mathrm{g} \mathrm{l^{-1 }}$, respectively).

\section{Microorganism abundance}

Large phytoplankton $\left(>10 \mu \mathrm{m}, 2.1[ \pm 1.9] \times 10^{4}\right.$ cells $\mathrm{I}^{-1}$ annual mean) and small phytoplankton $(<10 \mu \mathrm{m}, 1.1$ $[ \pm 0.9] \times 10^{7}$ cells $^{-1}$ annual mean) showed a simultaneous increase only in October. Three other major peaks occurred earlier in the year, in April $\left(5.2 \times 10^{4}\right.$ cells l$^{-1}$, mainly diatoms $)$, June $\left(4.8 \times 10^{4}\right.$ cells l$^{-1}$, diatoms and Dinophyceae) and August $\left(4.0 \times 10^{4}\right.$ cells l$^{-1}$, almost exclusively Dinophyceae) (Fig. 1). Small phytoplankton peaked in March (mainly Synechococcus), July (mainly picophytoplankton) and a major peak occurred in October (due to both).

The maximum variation in virus abundance was the 2.9 -fold difference observed between $1.3 \times 10^{7}$ viruses $\mathrm{ml}^{-1}$ in April and $3.75 \times 10^{7}$ viruses $\mathrm{ml}^{-1}$ in February. There were 3 periods when an increase in abundance occurred: in May, August and November. With an annual mean of $2.67( \pm 0.95) \times 10^{6}$ cells ml $^{-1}$, bacterial abundance varied from $1.53 \times 10^{6} \mathrm{cells} \mathrm{ml}^{-1}$ in December to $4.54 \times 10^{6} \mathrm{cells} \mathrm{ml}^{-1}$ in August. The dynamics of abundance featured 3 peaks, in February, April and August. The February and August peaks coincided with high values of viral abundance. In April it was decoupled from the viral dynamics and instead coincided with increases in diatom abundance (Fig. 1). The relationship between bacteria and viruses was weak $\left(\rho=0.15, p=0.63\right.$ and $r^{2}=0.051, p=0.48$ in linear regression where viruses were considered as a dependant variable), resulting notably from the clear uncoupling periods observed in April-May-June and October-November (grey area in Fig. 1, Table 2).

The annual mean heterotrophic nanoflagellate (HNF) concentration was $3.31( \pm 4.95) \times 10^{6}$ cells l$^{-1}$. Composed of $82 \%$ small size organisms $(<3 \mu \mathrm{m}), \mathrm{HNF}$ had 2 periods of growth, one in April $\left(2.54 \times 10^{6}\right.$ cells $\mathrm{1}^{-1}$ ) and a major one at the end of October, reaching $1.77 \times 10^{7}$ cells $\mathrm{l}^{-1}$ (Fig. 1). This high autumnal peak, $5 \times$ higher than the annual mean, was characterized by the exclusive development of $2 \mu \mathrm{m}$ HNF. Pigmented nanoflagellates represented $<10 \%$ of the total nanoflagellates, except in April and May when they reached 18 and $17 \%$, respectively.

The dynamics of ciliates $(3.78[ \pm 3.48]$ $\times 10^{3}$ cells $^{-1}$ annual mean) was characterized by 3 growth periods, in February $\left(4.45 \times 10^{3}\right.$ cells $\left.^{-1}\right)$, July $(1.23 \times$ 

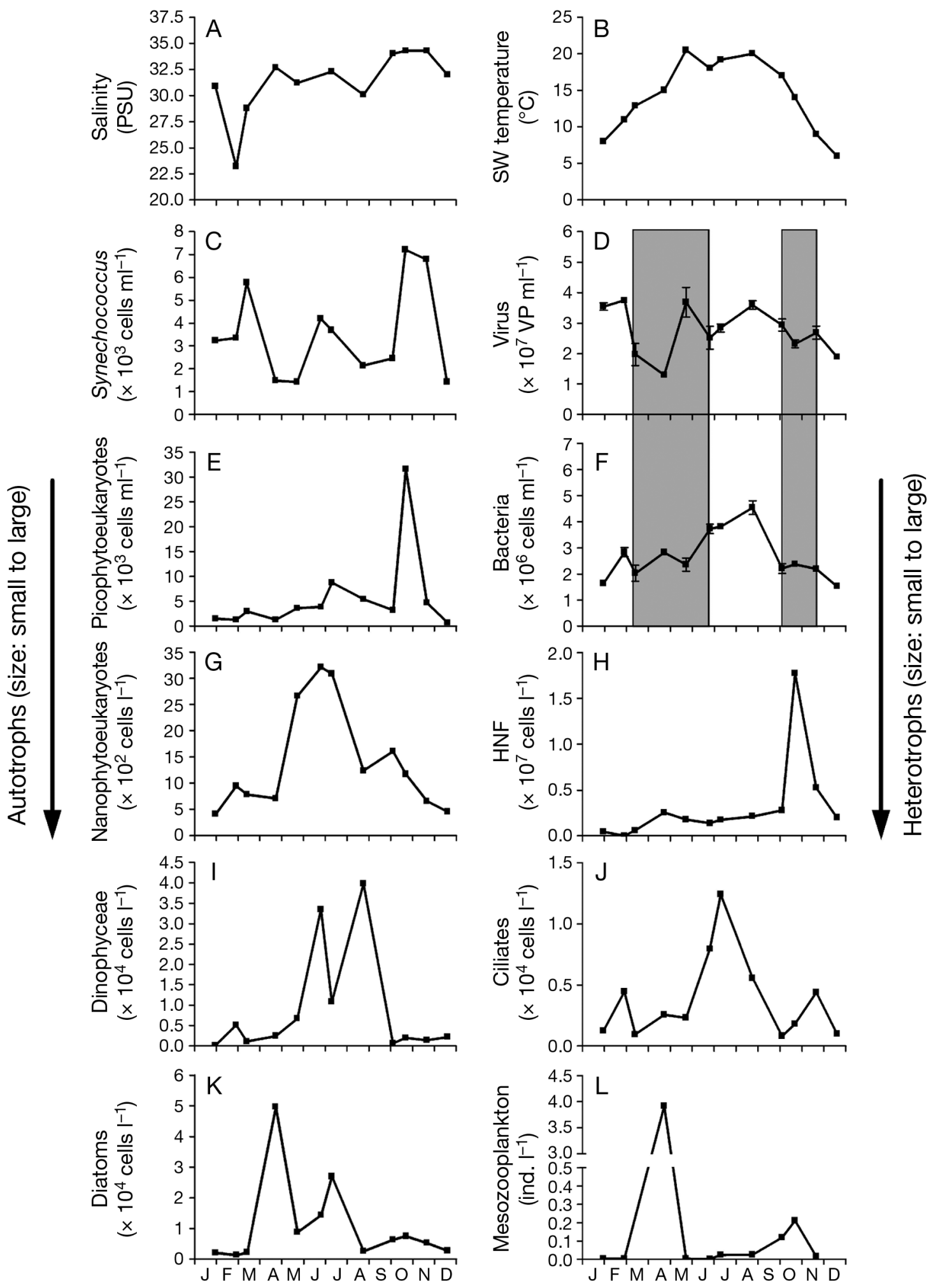

Fig. 1. Temporal dynamics of abiotic and biotic parameters. Survey performed during 2007 in Marennes Oléron Bay: (A) salinity; (B) seawater (SW) temperature; and abundance of (C) Synechococcus, (D) viruses, (E) picophytoeukaryotes, (F) bacteria, (G) nanophytoeukaryotes, (H) heterotrophic nanoflagellates (HNF), (I) Dinophyceae, (J) ciliates, (K) diatoms and (L) mesozooplankton. Only HNF, viral and bacterial abundance have a standard deviation scale. Organisms are classified as monitored with autotrophs on the left part and heterotrophs on the right part of the figure and according to their increasing size. Grey background in Panels D \& F marks the 2 periods of uncoupling. VP: viral particles 


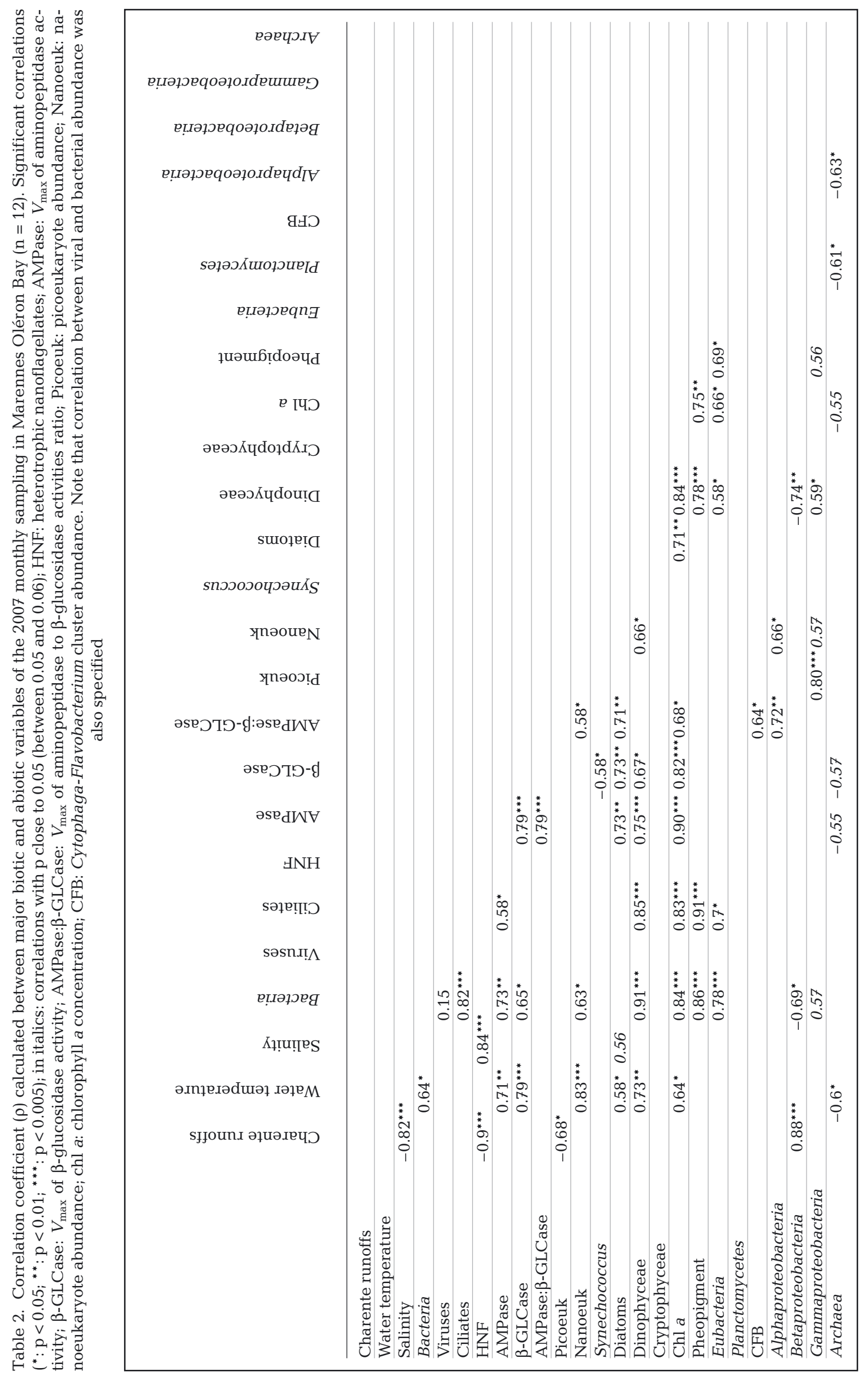




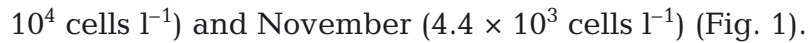
No synchronization with HNF dynamics occurred, except during the small April peak. Ciliates were significantly related to total bacterial abundance $(\rho=0.82$, $\mathrm{p}=0.001$; Table 2).

Mesozooplankton $\left(0.43[ \pm 1.2] \times 10^{4}\right.$ ind. $\mathrm{m}^{-3}$ annual mean) peaked mainly in April $\left(3.9 \times 10^{4}\right.$ ind. $\left.\mathrm{m}^{-3}\right)$ and at the end of October $\left(2.1 \times 10^{3}\right.$ ind. $\left.\mathrm{m}^{-3}\right)$ (Fig. 1).

\section{Bacterial enzymatic activity}

Total and specific exoenzymatic activities evolved similarly ( $\rho=0.89$ and 0.95 for AMPase and $\beta$-GLCase, respectively, $\mathrm{p}<0.001$ ) so only the total activity results were taken into account. Both potential AMPase and $\beta$-GLCase activities were significantly related ( $\rho=$ $0.79, p=0.002$ ) and had a concomitant major peak in

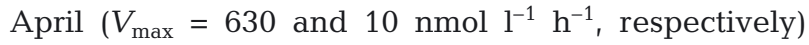
(Fig. 2). During the rest of the year, $V_{\max }$ AMPase peaked once in July (394 nmol $\mathrm{l}^{-1} \mathrm{~h}^{-1}$ ), while a $\beta$ GLCase peak occurred in August. With an annual

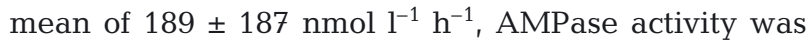
significantly higher than $\beta$-GLCase activity (4.1 \pm $2.9 \mathrm{nmol} \mathrm{l}^{-1} \mathrm{~h}^{-1}$ ). The AMPase: $\beta$-GLCase ratio varied between 13 in January and 78 in July; it increased during the spring period and at the end of October. AMPase and $\beta$-GLCase activities were closely and positively related to the chl a level $(\rho=0.90, p<0.001$ and $\rho=0.82, p=0.001$, respectively) and also to an abundance of large phytoplanktonic cells (diatoms: $\rho=0.73$, $p=0.007$ for AMPase and $\rho=0.73, p=0.007$ for $\beta$-GLCase). Nevertheless, the major peak of Dinophyceae in August coincided with the second peak of $\beta$-GLCase activity. The AMPase: $\beta$-GLCase ratio was positively correlated with the level of chl a $(\rho=0.71$, $\mathrm{p}=0.015)$ (Table 2).

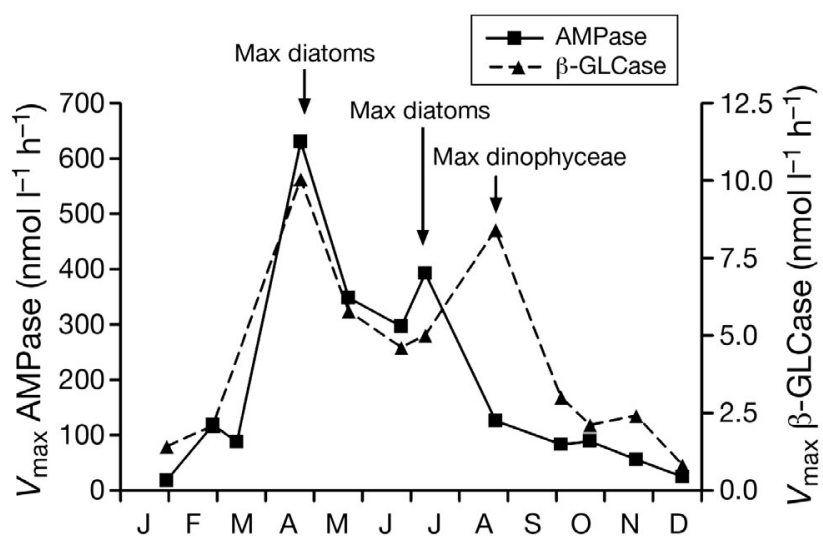

Fig. 2. Annual variation in the maximum hydrolysis potential $\left(V_{\max }\right)$ for 2 exoenzymatic activities, aminopeptidase (AMPase) and $\beta$-glucosidase ( $\beta$-GLCase)

\section{Bacterial community diversity}

Based on fluorescence in situ hybridization (FISH) results, Bacteria (Eub probe) represented between $40 \%$ in May and $81 \%$ in April of the total prokaryote community (DAPI counts) (Fig. S2 in the supplement at www.int-res.com/articles/suppl/a064p233_supp.pdf). The higher percentages were observed during winter and the first part of spring. Cells of the Archaea domain were scarce $\left(4.6[ \pm 6.9] \times 10^{4}\right.$ cells ml ${ }^{-1}$ annual mean), representing $<1 \%$ of the total prokaryote abundance for most of the year, except in January and at the end of October (9.7 and $9.2 \%$ of the prokaryotic community, respectively). Among all prokaryotes, from 42 to $81.5 \%$ of DAPI-stained cells were consistently detected. The frequency of FISH-targeted cells, belonging to the domains Eubacteria and Archaea, was in agreement with previous observations from many marine and estuarine ecosystems (reviewed in Bouvier \& Del Giorgio 2003). Within the Eubacteria domain, Betaproteobacteria and Gammaproteobacteria were the dominant bacterial groups, representing up to 12 and $13 \%$ of total bacteria, respectively, while Alphaproteobacteria cells generally remained below $1 \%$, except in July with $1.41 \%$ (Fig. S2). Gammaproteobacteria had an annual mean of $2.2( \pm 1.9) \times 10^{5}$ cells ml $^{-1}$ and dominated from June to September, reaching up to $5.7 \times 10^{5}$ cells ml ${ }^{-1}$, and in November $\left(2.5 \times 10^{5}\right.$ cells $\left.\mathrm{ml}^{-1}\right)$. Betaproteobacteria $\left(7.9[ \pm 7.6] \times 10^{4}\right.$ cells ml $\mathrm{m}^{-1}$ annual mean) were dominant in winter $\left(2.4 \times 10^{5}\right.$ cells $\mathrm{ml}^{-1}$ maximum reached in March) and at the beginning of October (up to $9.1 \times 10^{4}$ cells $\mathrm{ml}^{-1}$ ). Betaproteobacteria was the only bacterial group that showed a significant correlation with the Charente River runoff ( $\rho=$ $0.88, \mathrm{p}<0.001$ ). Finally, the CFB group and Planctomycetes always represented $<0.5 \%$ of the total community.

\section{Viral community composition}

The repeated profiles of both amplification and gel triplicates showed an average similarity of $84.3 \%$, ranging from 73.3 to $100 \%$ homology $(n=12$, data not shown).

The viral origin of the RAPD-PCR products was confirmed by comparing the banding patterns of amplicons from viral concentrates with or without DNase treatment. The efficiency of both DNase treatment and decapsidation was standardized with a lambda virus genome and T2 particles, respectively (Fig. S3A,B in the supplement at www.int-res.com/articles/suppl/ a064p233_supp.pdf). Notably, since no difference was observed between the use of both buffers in the DNase-treatment, we chose the Taq-polymerase buffer 
to avoid any possible inhibition in the PCR. Moreover, the higher the DNase quantities in contact with decapsidated T2 DNA, the weaker the subsequent amplification of free DNA (Fig. S3B). Our DNase test procedure was efficient at hydrolyzing T2 DNA only after decapsidation of the genome, even if some DNase-resistant templates tended to remain, inferring the successful liberation of the viral genome during decapsidation. Concerning environmental viral samples, DNase treatment on viral particles did not affect the banding profiles of the templates (Fig. S3C). The use of 1 and $5 \mathrm{U}$ of DNase induced a drop in banding pattern intensity, but without significant band losses compared to the control (80 and $90.9 \%$ of similarity for April and November samples, respectively; Dice Index).

RAPD fingerprint profiles showed up to 46 bands with the CRA22 primer, ranging from 130 to $1600 \mathrm{bp}$, and up to 18 bands with the OPA13 primer, ranging from 200 to $1000 \mathrm{bp}$ (Fig. 3). The number of distinct amplicons produced in each sample was higher with CRA22 than with OPA13 $(14 \pm 2.8$ vs. $5 \pm 2.4$ respective annual means). The comparison of profiles, generated by both primers over time, revealed a similar trend in the changes of fingerprint richness. However, no significant correlation was observed for the number of observed bands between the primers $(\rho=0.43, \mathrm{p}=$ $0.13)$.

The fingerprints of the last 4 mo of the year were clearly different from those of the other 8 mo of the year with both CRA22 and OPA13. The mean size of fingerprint amplicons was significantly higher during these months than during the rest of the year $(630 \pm 74$ and $655 \pm 24$ bp vs. $503 \pm 56$ and $498 \pm 153$ bp with CRA22 and OPA13 primers, respectively; $t$-test, $\mathrm{p}<$ 0.05). The viral community composition obtained with CRA22 was characterized by the occurrence of specific bands in April (170 and 220 bp amplicons), May (150, 275, 300 and $1400 \mathrm{bp}$ amplicons) and June (160 bp amplicon) (Fig. 3). Moreover, amplicons of around $300 \mathrm{bp}$ were of higher intensity for these 3 mo. Concerning the OPA13 profiles, a 200 bp amplicon characterized the month of April, while a 260 bp band was present throughout the year.

\section{Changes in viral community composition}

The MDS ordination performed either on viral community composition defined with CRA22 or on environmental variables described a good ordination with no real prospect of misleading interpretation (plot stress value of 0.1 ). The MDS ordination of viral community composition (Fig. 4A1) showed 3 different clusters separated at the $35 \%$ similarity threshold (based on clustering analysis from the Bray-Curtis similarity matrix): (1) January, February, March, April and August; (2) May, June and July; and (3) 4 October, 22 October, November and December. Non-parametric ANOSIM confirmed the robustness of the 3 clusters $(\mathrm{R}=0.863, \mathrm{p}=0.001)$. The BEST procedure revealed 4 environmental variables that explained the changes in viral community composition: AMPase activity, bacter-
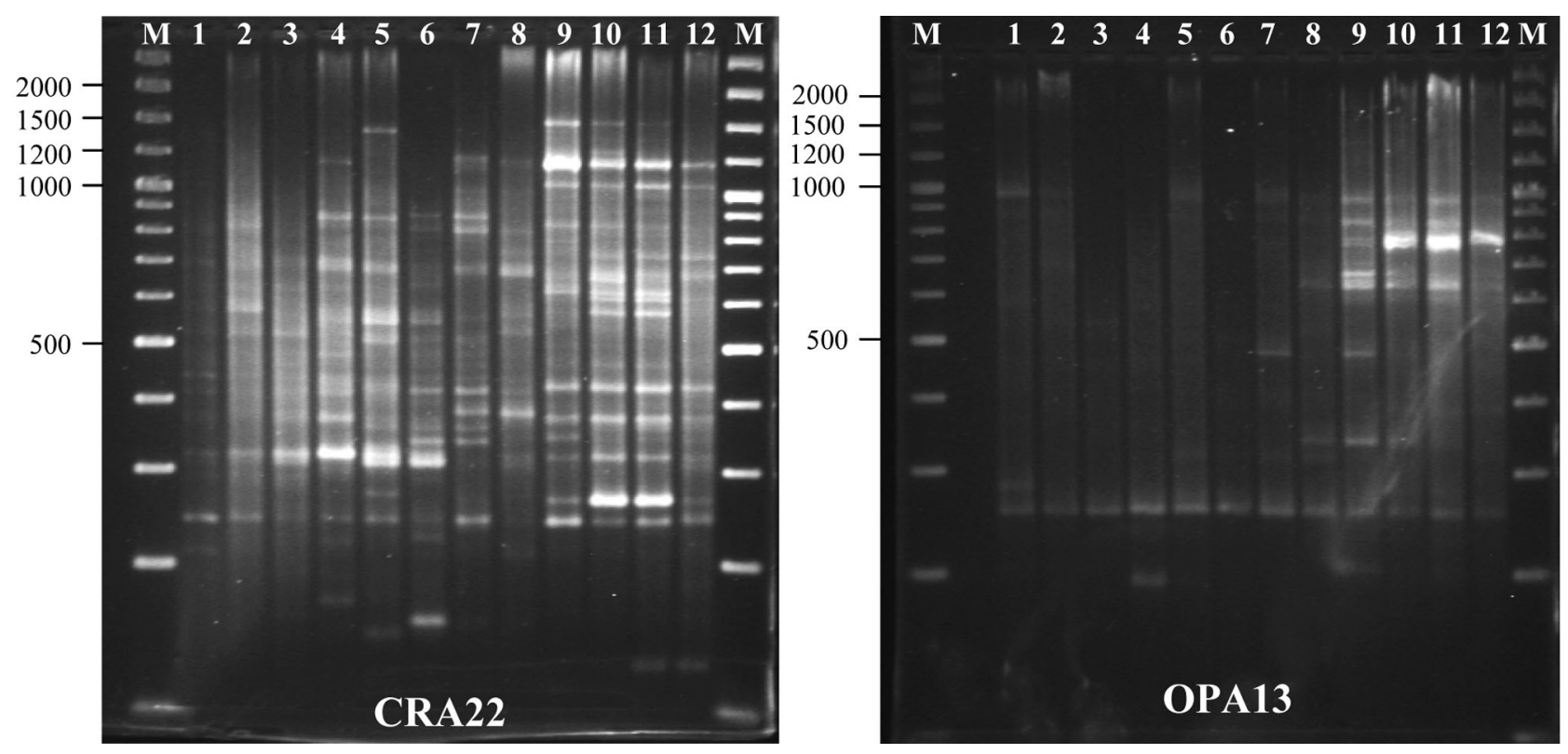

Fig. 3. Gels of primer CRA22 and OPA13 RAPD-PCR products. Numbers from 1 to 12 represent monthly samples. M: 100 bp ladder with selected marker sizes to the left of the gel (Fermentas) 

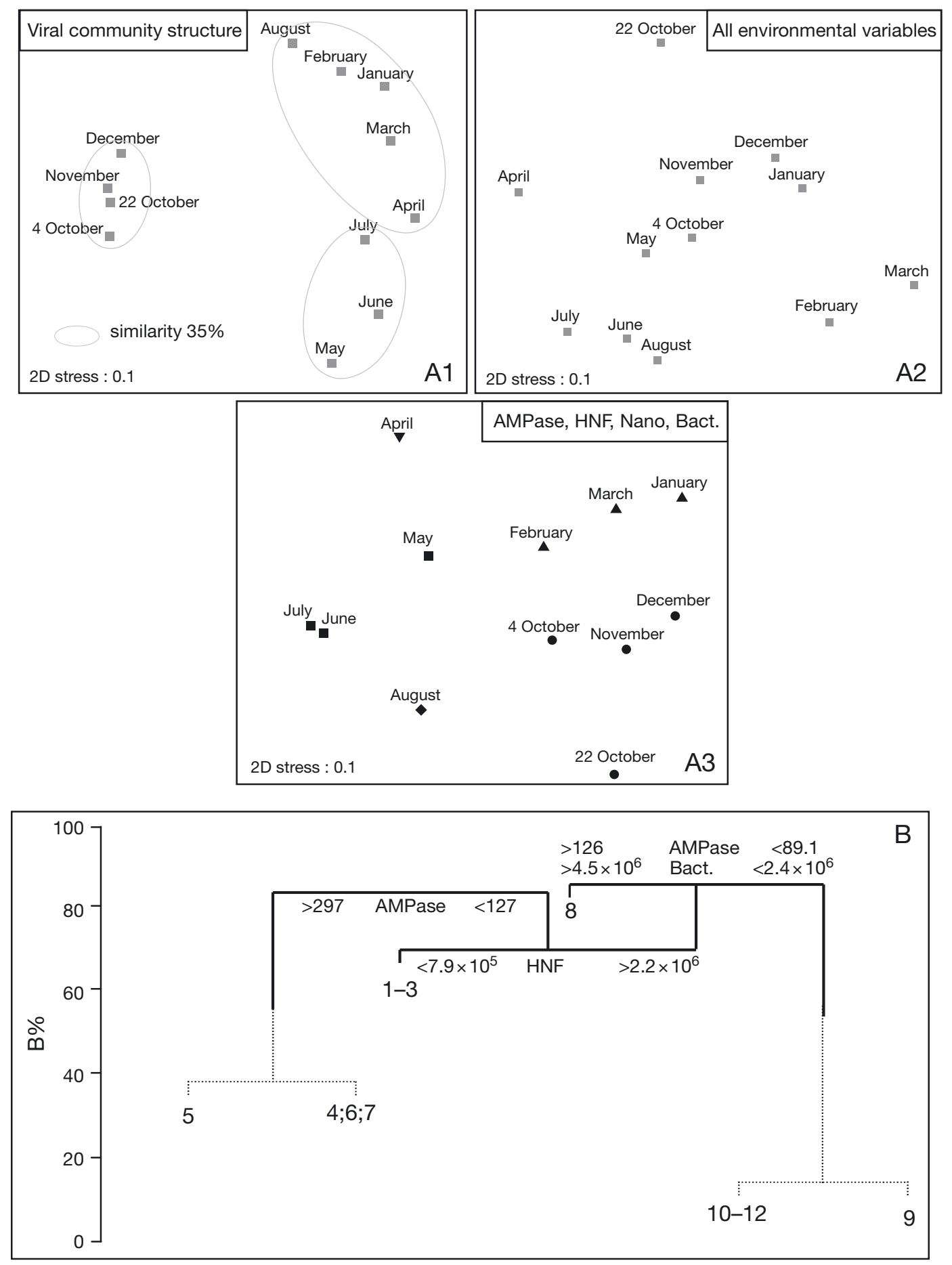

Fig. 4. Structure of the viral community. (A) Non-metric multi-dimensional scaling ordinations of the 12 monthly samples based on: (Panel A1) viral community composition, 35\% of similarity was based on the result of a cluster dendrogram from fourth-roottransformed data (not shown); (Panel A2) the 19 environmental variables: water temperature, salinity, bacterial abundance, viruses, ciliates and HNF, $V_{\max }$ of aminopeptidase and $\beta$-glucosidase activities, abundance of picophytoeukayotes, nanophytoeukaryotes, Synechococcus, diatoms, Dinophyceae and Cryptophyceae, abundance of Alpha-, Beta-, Gammaproteobacteria and Archaea and Charente River runoffs; and (Panel A3) subset of environmental variables 'best matching' the viral pattern, as selected by the BIO-ENV procedure. (B) A linkage tree of the viral community composition with a similarity scale bar defined as decreasing B\%. Each division was described by inequalities in the explanatory data best matching the viral structure selected by the BIO-ENV procedure. The dotted line describes non-significant sub-groups: the separation of 5 from 4, 6 and 7 was based on bacterial abundance, and 9 from 10, 11 and 12 was based on nanophytoeukaryotic abundance. AMPase: aminopeptidase activity;

HNF: heterotrophic nanoflagellate abundance; Nano: nanophytoeukaryote abundance; Bact: bacterial abundance 
ial abundance, HNF abundance and nanoeukaryote abundance $(\rho=0.425, p=0.07$, number of permutations $=99$ ). MDS ordination based on the 4 selected experimental variables clustered 5 different groups, including 2 isolated monthly samples (April and August): (1) January, February and March; (2) May, June and July; and (3) 4 October, 22 October, November and December (Fig. 4A3).

Using the extracted explanatory data, a clustering dendrogram (LINKTREE procedure) of the monthly viral community structure showed 4 significant clusters (Fig. 4B): (1) the spring months $(4,5,6$ and 7$)$ with an $84 \%$ difference (B\%) compared with the rest of the year $(\mathrm{R}=0.53, \mathrm{p}=0.001)$; (2) the winter months $(1,2,3)$ with a $69 \%$ difference with the rest of the samples $(\mathrm{R}=$ 0.56, $\mathrm{p}=0.001$ ); and (3) August (8) distinguished (86\%) from the last cluster (4) composed of the autumn months (9 to 12) ( $\mathrm{R}=1, \mathrm{p}=0.001)$.

The clustering, based on the distribution of viral amplicon band sizes, can therefore be explained by examining the explanatory variables. The winter cluster $(1,2$ and 3, CRA22 primer) was characterized by a low level of AMPase activity $\left(<127 \mathrm{nmol} \mathrm{l}^{-1} \mathrm{~h}^{-1}\right)$ combined with few HNFs $\left(<7.9 \times 10^{5}\right.$ cells l$\left.^{-1}\right)$. A lower AMPase level $\left(<127 \mathrm{nmol} \mathrm{l}^{-1} \mathrm{~h}^{-1}\right)$ occurred in late summer and autumn (8 to 12), combined with a higher HNF abundance $\left(>2.2 \times 10^{6}\right.$ cells $\left.\mathrm{l}^{-1}\right)$. The August sample was distinct from the autumnal months (9 to 12) because of its high bacterial abundance $(>4.5 \times$ $10^{6}$ cells $\mathrm{ml}^{-1}$ ) and its high AMPase concentration $\left(>126 \mathrm{nmol} \mathrm{l}^{-1} \mathrm{~h}^{-1}\right.$ ). Spring and early summer months were distinguished differently according to the primer used. With CRA22, 4, 5, 6 and 7 were grouped without distinction, and their viral community composition was related exclusively to high AMPase $\left(>297 \mathrm{nmol} \mathrm{l}^{-1} \mathrm{~h}^{-1}\right)$. With OPA13, nanophytoplankton abundance appeared to be an explanatory parameter of viral diversity, distinguishing June from the rest of the samples $(>3.2 \times$

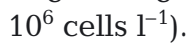

The OPA13 primer LINKTREE analysis was performed, but the results should be treated carefully because of the very low number of bands detected in each sample. However, AMPase and HNF were confirmed as explanatory variables, although, interestingly, salinity and river runoffs interceded in the changes in viral community composition, setting apart February and March (data not shown).

\section{DISCUSSION}

\section{Methodological considerations}

On a temporal scale, the entire microbial community structure is likely to change within a day or week, with different generation times and temporal variability in biological responses to biological and environmental factors (Hewson \& Fuhrman 2006, Fuhrman 2009). However, considering the number of parameters examined here, a long-term survey using a weekly or even a shorter time scale was inconceivable.

Fixation and conservation of viral samples are known to be quite uncertain processes that may induce variable losses of total viral counts compared to in situ concentrations (Brussaard 2004). Drops of 20 to $35 \%$ in viral abundance have been reported after a few hours in the presence of fixatives (glutaraldehyde or formaldehyde) and storage at $4^{\circ} \mathrm{C}$ with pelagic samples (Wen et al. 2004), as well as with viruses from estuarine sediments (Helton et al. 2006). However, in the present study, all samples were treated in the same way, allowing valuable cross-comparisons.

Seasonal variations in bulk viral abundance $(2.75$ $[ \pm 0.8] \times 10^{7}$ viruses $\mathrm{ml}^{-1}$ ) and fluctuations due to the concentration processes (coefficient of variation of $76 \%$ ) resulted in variable viral titers in the target samples (from $2 \times 10^{6}$ to $4 \times 10^{7}$ viruses $\mathrm{ml}^{-1}$ ) and may have introduced a possible bias in the amplification of rare species. In order to evaluate this bias and given that PCR inhibitors prohibited the addition of $>1 \mu \mathrm{l}$ of viral suspension, we also performed RAPDPCR by adding a constant abundance of viruses $(2 \times$ $10^{6}$ viruses) based on the least concentrated sample (Fig. 5). Both amplification reactions using the CRA22 primer provided the same results for the specific richness and relative quantity of amplicons between the 2 patterns (data not shown). Considering that the use of a specific viral titer was no more representative of the bulk diversity than the use of a unique volume and that the use of a constant percentage of bulk abundance was not possible, we regard the choice of identical volumes $(1 \mu \mathrm{l})$ as a valid way of studying the structure of viral communities. RAPD-PCR fingerprinting was considered as a useful analysis to assess viral community composition, assuming the uniqueness of viral species origin for each amplicon. However, recent in silico investigations confirmed current thinking by reporting that 26 to $33 \%$ of targeted phage genome (of a total of 85 complete genomes) may be amplified in 2 or more fragments (Winter \& Weinbauer 2010). Nevertheless, this fingerprinting method is sufficiently accurate to investigate changes in viral community structure, while the choice of primer is preponderant in discriminating between different subsets of environmental viruses. We confirmed that CRA22 is more discriminative than OPA13 (in terms of number of bands), although the latter may be useful for the characterization of the potentially different responses of targeted population subsets. 

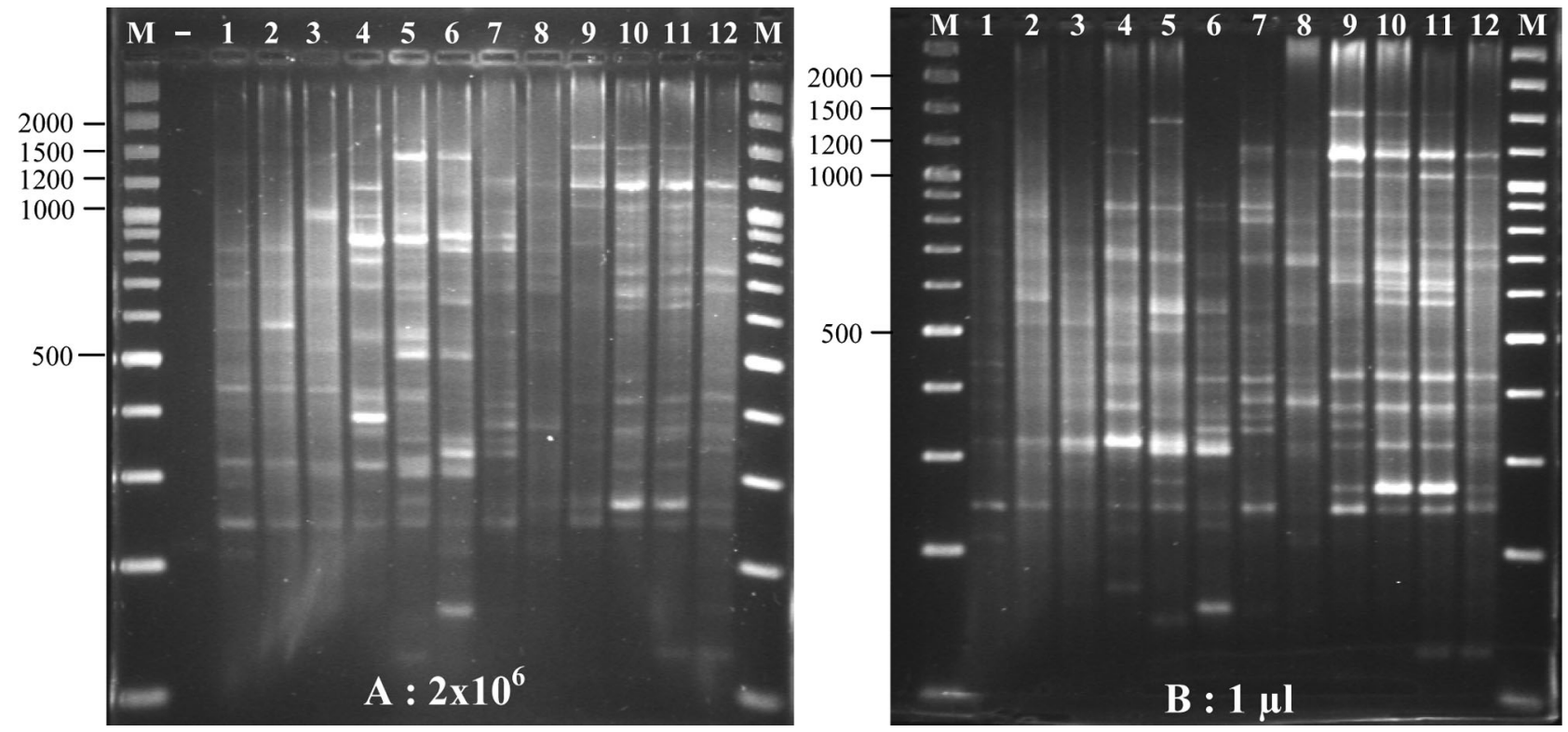

Fig. 5. Validation of the RAPD-PCR method. Electrophoregrams resulting from amplifications performed with the CRA22 primer of either a constant abundance of viruses (A: $2 \times 10^{6}$ viruses) or a constant volume of viral suspension (B: $\left.1 \mu \mathrm{l}\right)$. M: $100 \mathrm{bp}$ ladder (Fermentas); numbers from 1 to 12: monthly samples; -: negative control

\section{Monthly dynamics}

This 2007 survey gave unexpected results concerning micro-organism dynamics and their relationships (Fig. 1, Table 2). First, the annual means of primary and secondary producers were consistent with previous data only for Dinophyceae and Synechococcus, but were otherwise lower (Auguet et al. 2005, Ory et al. 2010). Indeed, among small phytoplankton cells, picoand nano-phytoeukaryotes showed an annual mean that was about 3 times lower than that of the previous year. The most important difference concerned diatoms, which had a 6-fold lower mean abundance in 2007. Mean bacterial and viral abundances (1.5-fold lower than in 2003 and 2006) remained quite constant over the year, without the usual large summer peaks (Auguet et al. 2005, Ory et al. 2010). However, the periods of viral increase were close to those obtained in the 2006 survey, although this was not the case for bacterial dynamics.

The evaluation of bacterial cell activity based on the measurement of exoenzymatic activity was consistent with results obtained previously: in 2003, at the same sampling station, potential AMPase activity ranged between 0.02 and $1.3 \mu \mathrm{mol} \mathrm{l}^{-1} \mathrm{~h}^{-1}$ (D. Delmas unpubl. data). Although bacterial activities in 2007 did not reach the level attained in 2003, cell-specific proteolysis activity was similar during these $2 \mathrm{yr}$ (mean of $66 \pm$ $63 \mathrm{amol} \mathrm{cell}^{-1} \mathrm{~h}^{-1}$ vs. $115 \pm 121 \mathrm{amol} \mathrm{cell}^{-1} \mathrm{~h}^{-1}$ ). In addition, the values of the AMPase and $\beta$-GLCase activities described here fell within the range of the published data from coastal or estuarine waters (Chróst \& Velimirov 1991, Karner \& Herndl 1992, Cunha \& Almeida 2009). Moreover, $\beta$-GLCase activity was between 10- and 100-fold lower than AMPase activity, while the proteolysis:glycolysis ratio tended to be lower in the inner part of an estuary (8 to 160; Polymenakou et al. 2005) compared to coastal areas (about 1000; Christian \& Karl 1995). However, the glycolysis potential was not as strongly linked to microbial communities as that of AMPase activity (Table 2, Fig. 4). Indeed, the low values of $\beta$-GLCase $V_{\max }$ could be below the sensitivity threshold for a study of the covariations between community structure and activity. Moreover, a negligible importance of carbohydrates in bacterial diet has been shown (Zoppini et al. 2005). Nevertheless, higher uptakes of carbohydrates by bacteria have been described for members of the Alphaproteobacteria, at low ambient glucose concentrations (Alonso \& Pernthaler 2006). Indeed our sampling site, located at the river mouth, is characterized by few Alphaproteobacteria (Fig. S2).

Interestingly, ciliates were the only predators that correlated with bacterial abundance in the present study (Table 2). There is still a question mark over the prey selectivity of ciliates on bacteria, but it may be ciliate species specific and depend on the type and size of bacterial prey (Bernard \& Rassoulzadegan 1990, Ayo et al. 2001). Abundance and dynamics of grazers (ciliates and HNF) generally followed the same pattern of increase and decline as in the $2006 \mathrm{MOB}$ study (Ory et al. 2010), except that a much greater peak of HNF was 
observed in the autumn of 2007 (Fig. 1). Indeed, particularly strong increases were observed during this period for components of the microbial food web, a trophic pathway comprising small cell-producers and their protozoan predators (Legendre \& Rassoulzadegan 1995). Primary production in the autumn appeared to be based on small autotrophic cells such as picophytoeukaryotes and Synechococcus. Considering that HNF are major picoplankton grazers (Monger et al. 1999), the high peak of picophytoeukaryotes, as well as the small increase in bacteria, could sustain a strong increase in HNF, ciliates and lastly mesozooplankton (Fig. 1). During this productive period, Synechococcus were less abundant than picophytoeukaryotes, but their growth phase lasted longer. While picophytoeukaryotes may represent the main source of carbon for microzooplankton (ciliates), not only did Synechococcus appear to be weakly impacted by grazing, but also low viral lysis rates have been reported (Suttle \& Chan 1994, Worden et al. 2004, Baudoux et al. 2008).

\section{Virus-bacteria relationship}

No significant relationship existed between the dynamics of virus and bacteria in contrast to what is usually observed in most marine $\left(\mathrm{r}^{2}=0.94\right.$ to 0.67 ; Boehme et al. 1993, Cochlan et al. 1993), freshwater and estuarine areas $\left(\mathrm{r}^{2}=0.85\right.$; Auguet et al. 2005). However, 3 reviews of studies performed in freshwater sites and marine sites described the large variation in the strength of the relationship $\left(\mathrm{r}^{2}\right)$ between viral and bacterial abundance and also in terms of the powerslope of the regression (Maranger \& Bird 1995, Gasol \& Duarte 2000, Clasen et al. 2008). In the present study, relatively weaker abundance oscillations and uncoupled viral and bacterial dynamics for 5 samples out of 12 explained this poor relationship (Fig. 1). This uncoupling may result from a relatively greater lytic induction of lysogenic bacteria and/or variations in the viral burst size according to temperature or trophic status, leading to a release of more virions (Parada et al. 2006). Recently, Motegi et al. (2009) suggested that nutrientrich conditions entailed increasing the expression of the antiphage traits of bacteria and/or the destruction of viral capsids by bacterial extracellular proteases.

Furthermore, the complexity of the MOB ecosystem is under the temporal variations of inputs from the Charente River (allochthonous viruses and bacteria; Auguet et al. 2005). Changes in morphological (transmission electron microscopy) and virus-like genome structures (pulsed-field gel electrophoresis, PFGE) were reported along the salinity gradient of the Charente River (Auguet et al. 2006). In addition, riverine viruses transferred to MOB could express their infec- tious potential through estuarine bacterial communities (Auguet et al. 2008). Here, the use of the 2 primers, CRA22 and OPA13, may describe 2 temporal changes of viral community structures since they target 2 different subsets of the viral community (Winter \& Weinbauer 2010). The link between the viral community subset amplified with OPA13 and the salinity could infer the presence of some virus/host systems of riverine origin (data not shown). Bacterial community composition was also under the influence of Charente River inputs. During winter, when nutrients were not limiting, the dominant group tended to be Betaproteobacteria (Fig. S2). The Betaproteobacteria group is known to belong mainly to the freshwater prokaryote community, but its presence has been reported in coastal waters (Giovannoni \& Rappé 2000). Currently, it is unclear if this community represents an active marine bacterial group or if it is passively carried with freshwater outputs to the coastal zone. The strong correlation between the presence of Betaproteobacteria and the Charente River outputs corroborates the second hypothesis, but their constant presence and their reactivity to the manipulation of flagellates or viruses (Ory et al. 2010) support their involvement in the coastal microbial loop.

\section{Temporal dynamics of the viral community structure}

The potential link between viral and bacterial abundance or bacterial community composition (BCC) was not clearly demonstrated here. The viral phylogenetic level analyzed may have been too detailed to detect significant correlations with the taxonomic groups of prokaryotes (Bacteria and Archaea). Interestingly, a strong statistical link was found between the variation in viral community structure and the potential of bacterial exoenzymatic activity, particularly AMPase, despite the difference in analysis level (species level for viral community structure and overall community level for bacterial exoenzymatic activities; Fig. 4). Thus, bacterial exoenzymatic activity may be considered as an integrator of different processes acting at different trophic levels. The link between the viral fingerprints and AMPase could reflect direct and indirect interactions between viruses and bacteria, taking into account the influences of phytoplankton and grazer activities.

We therefore hypothesized that viral community structure could partly depend on phytoplankton, either directly through phytoplankton viruses, or indirectly through the uptake or transformation by bacteria of DOM or organic compounds excreted from autotrophic cells. However, this assumption had to be moderated since DOM may also originate from viral lysis, grazers 
and from allochthonous inputs. Thus, the weaker relationship between viral and bacterial abundance could be the result of viruses infecting other organisms. Indeed, links between viral abundance and autotrophic parameters have already been described (Boehme et al. 1993, Maranger et al. 1994, Maranger \& Bird 1995, Guixa-Boixereu et al. 1999, Clasen et al. 2008, Jackson \& Jackson 2008, Ory et al. 2010). Moreover, phytoplankton community composition has already been proposed as a proxy for evaluating the organic carbon resources available to aquatic bacteria and driving shifts in bacterial community dynamics and structure, although bacteria may be synchronizing phytoplankton dynamics through nutrients (Kent et al. 2007). Proteolysis activity may, therefore, reflect phytoplankton-bacteria interactions and their relationships with viruses, supported by the strong statistical correlation between chl $a$ and AMPase activity (Table 2).

Among the factors explaining the variation in viral community structure (Fig. 4), the potential AMPase activity differentiated spring and autumnal phytoplankton blooms, concomitant with the uncoupling in virus-bacteria abundance. Both periods were characterized by high viral richness (as shown by the number of bands) and the emergence of specific bands, but differed in proteolysis level (high in spring and low in autumn). Would changes in bacterial community structure be synchronized or not with changes in viral community structure? Our data were not sufficient to clarify this point.

\section{Virus-bacteria interactions}

Assuming that viruses in coastal environments are mainly bacteriophages (Wommack et al. 1992, Maranger \& Bird 1995), their multiplication depends on the density of sensitive and permissive bacterial cells, whose abundance varies according to different factors such as bacterial community structure or physiological status. Thus, the virioplankton lytic activity is known to impact bacterial community composition (Hewson \& Fuhrman 2007). Many hypotheses suggest that the species diversity of the hosts (specific richness) is not only sustained by adaptation to ecological niches (Fuhrman et al. 2006) but also by viral infection. (1) According to the 'kill the winner' theory, since viral infection depends on bacterial density, viruses may modulate bacterial community composition by regulating the dominant bacterial groups and thus may favor the presence of rare and less competitive populations (Thingstad 2000). (2) Moreover, Bouvier \& Del Giorgio (2007), on the basis of in vitro experiments, concluded that virussensitive groups may be the rare bacterial groups that are more metabolically competitive for resources. Their potential bloom may be regulated by viral lysis. Nevertheless, the specificity of viral infection and the vulnerability of prokaryotic hosts to $>1$ viral species remains in question (Winter et al. 2010). Intrinsic changes of bacterial cell-specific activity could induce an increase in bacterial sensitivity and permissivity to viruses by inducing changes in receptor regions of the bacterial cell membranes involved in nutrient uptake and also related to viral adsorption (Middelboe 2000), in fine resulting in an increase in viral yield (Bouvier \& Del Giorgio 2007, Auguet et al. 2008). This assumption is relevant to Sandaa et al. (2009), who hypothesized that the number of different virus-host pairs is controlled by viral lysis, and their identity, by substrate availability. Thus, viral community structure could be directly related to the most productive bacterial clones and, consequently, to bacterial proteolysis (Fig. 4B).

\section{Virus-phytoplankton interactions}

During the spring phytoplanktonic period, when the strongest virus-bacteria uncoupling occurs, phytoplankton viruses could partly regulate the large-phytoplankton bloom, which involves mainly diatoms. From our current knowledge, genomes of eukaryotic microalgal viruses range in size from 200 to $500 \mathrm{~kb}$, those of cyanophages from 30 to $380 \mathrm{~kb}$ and those of bacteriophages from 39 to $60 \mathrm{~kb}$ (Larsen et al. 2001, Baudoux et al. 2008, Sandaa 2008). For our study site using a PFGE analysis, a clear relationship was demonstrated in data from a 7 mo survey in 2002/2003: (1) between large virus-like genomes (VLG $>200 \mathrm{~kb}$ ) and large capsid size ( $>65 \mathrm{~nm}$ ) and (2) between small VLGs $(<100 \mathrm{~kb})$ and small capsid size $(<65 \mathrm{~nm})$ (Auguet et al. 2006). Thus, the occurrence of large VLGs (261 to $300 \mathrm{~kb}$ ) and the $50 \%$ contribution of large tailed phages $(\geq 105 \mathrm{~nm})$ to total tailed phages, reported in April 2003 (Auguet et al. 2006) during an uncoupling period with a low number of viruses, as in April 2007, may come from phycoviruses or cyanophages.

In autumn 2007, high peaks of small phytoplankton, mainly composed of picophytoeukaryotes and Synechococcus, may have allowed the development of viruses specific for these autotrophic groups (Fig. 1). During this period, the uniqueness of the viral fingerprint pattern also suggested the occurrence of phytoplankton viruses (Figs. 3 \& 4). Previously, in October $2003,9.8 \%$ of the VLP were $\geq 105 \mathrm{~nm}$ in size with $1 \%$ tailed phages (H. Montanié per. obs.), compensating for the presence of phytoplankton or cyanobacterial viruses during this autumnal period when virus numbers were low. As in their response to grazing, small phytoplankton could react differently to viral lysis depending on the cell group: Synechococcus would be 
less affected by viral lysis than picophytoeukaryotes (Baudoux et al. 2008). The 2 mo peak of Synechococcus lasted longer than the picophytoeukaryote peak and may corroborate the difference in the response to viruses (sensitivity, latency time and burst size) and in fine in the decline rate of microalgae. Indeed, it is established that the Synechococcus population resisted well to co-occurring phages due to variations in clonal composition according to acquisition of resistance by successive species (Waterbury \& Valois 1993, Marston \& Sallee 2003). In fine, their abundance regulation may therefore rely mainly on microzooplankton (Christaki et al. 1999).

\section{Top-down control by grazers}

BCC and bacterial activity varied experimentally with grazing pressure (Šimek et al. 1999, Jardillier et al. 2005). Zöllner et al. (2009), discussing the importance of specificity of predation, suggested that mesozooplankton, indirectly via the trophic cascade, sloppy-feeding and phytoplankton top-down control (Kragh \& Søndergaard 2004), and HNF, directly via predation, could affect the parameters of bacterial community activities more strongly than bacterial abundance (Van Wambeke 1994). The size-specific selectivity of HNF modified bacterial community composition and structure (Šimek et al. 2001). Similarly, in the present study, the apparently size-specific predation of ciliates on bacteria quantitatively related ciliates to the bacterial community, while the presumed host-specificity of viruses may induce qualitative links within the community (Table 2, Fig. 4). Phytoplanktonic blooms were also regulated by top-down control. In spring, this control was driven mainly by mesozooplankton, as happens during a typical phase of the herbivorous food web trophic model (Legendre \& Rassoulzadegan 1995). In autumn, the small-phytoplankters may be controlled sequentially by HNF, ciliates and mesozooplankton, as in a trophic model of the microbial food web. In 2007, the unusually high peak of nanoflagellates could have affected the number of VHS (Sandaa et al. 2009), as suggested by the higher viral richness observed in autumn.

\section{Resource-mediated control}

Bacterial activities were also under bottom-up pressure via the quantity and quality of available labile matter, mainly released by phytoplankton (Winter et al. 2010). Indeed, bacterial exoenzymatic activity depends on: (1) the quantity and quality of the labile substrate, mainly excreted by phytoplankters, by sloppy-feeding of grazers or by the bursting of virusinfected phytoplankton or bacterial cells (Cherrier et al. 1996, Middelboe \& Lyck 2002, Winter et al. 2004a, Brussaard et al. 2005) and (2) the BCC-comprising species, which may have different proteolysis or glycolysis capacities (Riemann et al. 2000). Thus, the supplies of organic matter may affect the magnitude of coupling between viruses and bacteria in the marine environment (Motegi et al. 2009).

The phytoplankton bloom enhanced the production of fresh organic matter (largely composed of polysaccharides and proteins; Ittekkot 1982) both directly through excretion or indirectly through grazing and sloppy-feeding (Jumars et al. 1989), which in turn induced higher potential bacterial enzymatic activity (Biddanda \& Benner 1997, Misic \& Fabiano 2006). In $\mathrm{MOB}$, dissolved organic carbon (DOC) was mainly a large fraction of labile matter (around 20\% assuming that both dissolved carbohydrates and proteins were labile; D. Delmas unpubl. data). The conservative aspect of DOC was proved all along the salinity gradient in the Charente River (i.e. DOC dilution is proportional to water mixing) and inferred significant riverine inputs into the basin (Auguet et al. 2005). Moreover, the DOC quality was characterized in MOB by lower carbohydrate levels (monomeric as well as polymeric) and a higher dissolved free amino acid concentration, as compared to the Charente River (Auguet et al. 2005). Thus, in a complex ecosystem like MOB, DOM composition may change according to: (1) high freshwater inputs that increase the carbohydrate concentration in the outer estuary (our sampling site) and (2) tidal resuspension of benthic sediment (Wainright 1990, Hopkinson et al. 1998). Annual variations in bacterial exoenzymatic activities in MOB reflected the DOC quality and the shifts in consumed DOM, as previously shown by Alonso-Saez et al. (2008). The proteolysis:glycolysis ratio, which was weak in August and November, corroborated previous time series results in Spain (Alonso-Saez et al. 2008) and the preferential degradation of polysaccharides during these 2 mo under a temperate climate.

The pool of organic matter available to bacteria was continuously fed from viral lysis and phytoplankton, and its quality varied according to the phytoplankton composition, which is also under the influence of viral lysis and grazing. In the present study, the difference in phytoplankton dynamics and composition could thus be responsible for the temporal changes in bacterial AMPase activity, as suggested by the concordance of changes in diatom abundance and proteolysis level (Fig. 2). Bacteria can respond rapidly to dissolved or particulate material associated with the phytoplankton bloom (Lancelot \& Billen 1984). Indeed, chl a concentrations and potential exoenzymatic activity have 
already been clearly related (Sala et al. 2005). Synchronous changes in diatom abundance and in proteolysis level in MOB may indicate, as suggested by Kent et al. (2007), that the resource-mediated (bottom-up) control is the mechanism by which an environmental signal is passed along from the phytoplankton to the bacterial communities.

In spring, the diatom bloom could induce the release of HMW compounds, including polypeptides, which stimulate bacterial cell activity via the production of the AMPase enzyme. In contrast, the small phytoplankton autumnal bloom: (1) did not seem to provide sufficient matter to strongly stimulate the potential exoenzymatic activity of bacteria, and their abundance remained low; (2) may repress this activity because of the low quality of released matter (more refractory HMW-DOM); or (3) the excreted LMW-DOM, derived from viral or grazing activity and/or of allochthonous origin, would be preferentially assimilated by bacteria (Azua et al. 2003, Berggren et al. 2010). Our results argue in favor of an indirect role for phytoplankton in the resource-mediated control of the type of VHS that is present.

\section{CONCLUSIONS}

The in situ survey of 2007 in MOB featured unexpected dynamics of pelagic microorganisms, notably an absence of large viral and bacterial peaks in the summer. Two periods of high viral specific richness with a concomitant uncoupling between viral and bacterial dynamics were clearly distinguished: (1) during the herbivorous spring period, large-phytoplankton blooms may be mainly regulated by mesozooplankton yet could sustain bacterial activity; (2) the trophic structure of the autumn months was characterized by the presence of a strong microbial food web promoting the transfer of organic matter from picophytoplankton to HNF and ciliates, but only weakly enhancing the bacterial standing stock. In both cases, the virus-bacteria uncoupling may be explained first by the simultaneous presence of microalgal viruses and the stimulation of bacterial growth by DOM released by phytoplankton and then by standard prey-predator interactions (virus and HNF as predators).

Interestingly, spring and autumnal shifts in viral community structure were related to the level of AMPase activity. We thus provide conclusive evidence on the importance of AMPase activity as a direct indicator of the phytoplankton influence over bacterioplankton, which indirectly attests to the ecosystem trophic pathway (herbivorous vs. microbial food web, concordant with the prevalence of large vs. small autotrophic cells). Overall, we demonstrated that pro- teolysis activity may reflect the phytoplankton-bacteria interactions and their relationship with viruses. For these reasons, we suggest using the AMPase activity level as a proxy in structuring virioplankton. However, it would be useful in a future work to approach bacterial community structure at the species level using fingerprinting techniques and to specify the origin of DOM using carbon stable isotope analysis.

Acknowledgements. The present study was partly supported by the French PNEC-Littoral Atlantique program. This paper was also a contribution to the AQUAPHAGE project funded by the French ANR Biodiversity program (ANR 07 BDIV 01505 awarded to H.M.). P. Ory's work was supported by a joint PhD fellowship from the CNRS and the Région Poitou-Charente. The authors thank P. Lebaron and P. Catala for cytometry analyses, M. Bréret and F. Mornet for microplankton counts, B. Sautour for mesozooplankton counts, P. Pineau, N. Lachaussée and D. Vilday for their sampling assistance and H. J. Hartmann for improving the manuscript. Two anonymous reviewers are gratefully acknowledged for their helpful comments.

\section{LITERATURE CITED}

Agusti S, Satta MP, Mura MP, Benavent E (1998) Dissolved esterase activity as a tracer of phytoplankton lysis: evidence of high phytoplankton lysis rates in the northwestern Mediterranean. Limnol Oceanogr 43:1836-1849

Alonso C, Pernthaler J (2006) Roseobacter and SAR11 dominate microbial glucose uptake in coastal North Sea waters. Environ Microbiol 8:2022-2030

Alonso-Saez L, Vazquez-Dominguez E, Cardelus C, Pinhassi $\mathrm{J}$ and others (2008) Factors controlling the year-round variability in the carbon flux through bacteria in a coastal marine system. Ecosystems 11:397-409

Amann RI, Ludwig W, Schleifer KH (1995) Phylogenetic identification and in situ detection of individual microbial cells without cultivation. Microbiol Rev 59:143-169

Auguet JC, Montanie H, Delmas D, Hartmann HJ, Huet V (2005) Dynamic of virioplankton abundance and its environmental control in the Charente estuary (France). Microb Ecol 50:337-349

Auguet JC, Montanié H, Lebaron P (2006) Structure of virioplankton in the Charente estuary (France): transmission electron microscopy versus pulsed field gel electrophoresis. Microb Ecol 51:197-208

Auguet JC, Montanie H, Hartmann HJ, Lebaron P, Casamayor EO, Catala P, Delmas D (2008) Potential effect of freshwater virus on the structure and activity of bacterial communities in the Marennes-Oléron Bay (France). Microb Ecol 57:295-306

Ayo B, Santamaria E, Latatu A, Artolozaga I, Azua I, Iriberri J (2001) Grazing rates of diverse morphotypes of bacterivorous ciliates feeding on four allochthonous bacteria. Lett Appl Microbiol 33:455-460

Azua I, Unanue M, Ayo B, Artolozaga I, Arrieta JM, Iriberri J (2003) Influence of organic matter quality in the cleavage of polymers by marine bacterial communities. J Plankton Res 25:1451-1460

> Baudoux AC, Veldhuis MJW, Noordeloos AAM, van Noort G, Brussaard CPD (2008) Estimates of virus- vs. grazing induced mortality of picophytoplankton in the North Sea during summer. Aquat Microb Ecol 52:69-82 
Berggren M, Laudon H, Haei M, Ström L, Jansson M (2010) Efficient aquatic bacterial metabolism of dissolved lowmolecular-weight compounds from terrestrial sources. ISME J 4:408-416

> Berglund J, Samuelsson K, Kull T, Müren U, Andersson A (2005) Relative strength of resource and predation limitation of heterotrophic nanoflagellates in a low-productive sea area. J Plankton Res 27:923-935

Bernard C, Rassoulzadegan F (1990) Bacteria or microflagellates as a major source for marine ciliates: possible implications for the microzooplankton. Mar Ecol Prog Ser 64: $147-155$

Biddanda B, Benner R (1997) Carbon, nitrogen, and carbohydrate fluxes during the production of particulate and dissolved organic matter by marine phytoplankton. Limnol Oceanogr 42:506-518

Boehme J, Frischer ME, Jiang SC, Kellogg CA and others (1993) Viruses, bacterioplankton, and phytoplankton in the southeastern Gulf of Mexico: distribution and contribution to oceanic DNA pools. Mar Ecol Prog Ser 97:1-10

> Borsheim KY, Bratbak G, Heldal M (1990) Enumeration and biomass estimation of planktonic bacteria and viruses by transmission electron microscopy. Appl Environ Microbiol 56:352-356

Bouvier T, Del Giorgio PA (2003) Factors influencing the detection of bacterial cells using fluorescence in situ hybridization (FISH): a quantitative review of published reports. FEMS Microbiol Ecol 44:3-15

Bouvier T, Del Giorgio PA (2007) Key role of selective viralinduced mortality in determining marine bacterial community composition. Environ Microbiol 9:287-297

> Bratbak G, Egge JK, Heldal M (1993) Viral mortality of the marine alga Emiliania huxleyi (Haptophyceae) and termination of algal blooms. Mar Ecol Prog Ser 93:39-48

Brussaard CPD (2004) Optimization of procedures for counting viruses by flow cytometry. Appl Environ Microbiol 70: 1506-1513

> Brussaard CPD, Riegman R, Noordeloos AAM, Cadée GC and others (1995) Effects of grazing, sedimentation and phytoplankton cell lysis on the structure of a coastal pelagic food web. Mar Ecol Prog Ser 123:259-271

Brussaard CPD, Mari X, Van Bleijswijk JDL, Veldhuis MJW (2005) A mesocosm study of Phaeocystis globosa (Prymnesiophyceae) population dynamics. II. Significance for the microbial community. Harmful Algae 4:875-893

> Cherrier J, Bauer JE, Druffel ERM (1996) Utilization and turnover of labile dissolved organic matter by bacterial heterotrophs in eastern North Pacific surface waters. Mar Ecol Prog Ser 139:267-279

> Christaki U, Jacquet S, Dolan JR, Vaulot D, Rassoulzadegan F (1999) Growth and grazing of Prochlorococcus and Synechococcus by two marine ciliates. Limnol Oceanogr 44 : $52-61$

> Christian JR, Karl DM (1995) Bacterial ectoenzymes in marine waters: activity ratios and temperature responses in three oceanographic provinces. Limnol Oceanogr 40: 1042-1049

Chróst RJ (1992) Significance of bacterial ectoenzymes in aquatic environments. Hydrobiologia 243/244:61-70

Chróst RJ, Velimirov B (1991) Measurement of enzyme kinetics in water samples: effect of freezing and soluble stabilizer. Mar Ecol Prog Ser 70:93-100

Clarke KR, Ainsworth M (1993) A method of linking multivariate community structure to environmental variables. Mar Ecol Prog Ser 92:205-219

Clarke KR, Gorley RN (2006) PRIMER 6 user manual/tutorial. PRIMER-E, Plymouth
Clasen JL, Brigden SM, Payet JP, Suttle CA (2008) Evidence that viral abundance across oceans and lakes is driven by different biological factors. Freshw Biol 53:1090-1110

- Cochlan WP, Wikner J, Steward GF, Smith DC, Azam F (1993) Spatial distribution of viruses, bacteria and chlorophyll a in neritic, oceanic and estuarine environments. Mar Ecol Prog Ser 92:77-87

Cunha A, Almeida A (2009) Inorganic nutrient regulation of bacterioplankton heterotrophic activity in an estuarine system (Ria de Aveiro, Portugal). Hydrobiologia 628:81-93

> Delmas D, Garet MJ (1995) SDS-preservation for deferred measurement of exoproteolytic kinetics in marine samples. J Microbiol Methods 22:243-248

> DeLong EF, Wickham GS, Pace NR (1989) Phylogenetic stains: ribosomal RNA-based probes for the identification of single cells. Science 243:1360-1363

Fuhrman JA (1999) Marine viruses and their biogeochemical and ecological effects. Nature 399:541-548

Fuhrman JA (2009) Microbial community structure and its functional implications. Nature 459:193-199

Fuhrman JA, Noble RT (1995) Viruses and protists cause similar bacterial mortality in coastal seawater. Limnol Oceanogr 40:1236-1242

Fuhrman JA, Schwalbach M (2003) Viral influence on aquatic bacterial communities. Biol Bull 204:192-195

Fuhrman JA, Griffith JF, Schwalbach MS (2002) Prokaryotic and viral diversity patterns in marine plankton. Ecol Res 17:183-194

Fuhrman JA, Hewson I, Schwalbach MS, Steele JA, Brown MV, Naeem S (2006) Annually reoccurring bacterial communities are predictable from ocean conditions. Proc Natl Acad Sci USA 103:13104-13109

Gasol JM, Duarte CM (2000) Comparative analyses in aquatic microbial ecology: How far do they go? FEMS Microbiol Ecol 31:99-106

Gastrich MD, Leigh-Bell JA, Gobler CJ, Anderson OR, Wilhelm SW, Bryan M (2004) Viruses as potential regulators of regional brown tide blooms caused by the alga, Aureococcus anophagefferens. Estuaries 27:112-119

Giovannoni SJ, Rappé MS (2000) Evolution, diversity, and molecular ecology of marine prokaryotes. In: Kirchman DL (ed) Microbial ecology of the oceans. Wiley-Liss, New York, NY, p 47-84

Guixa-Boixereu N, Vaqué D, Gasol JM, Pedros-Alio C (1999) Distribution of viruses and their potential effect on bacterioplankton in an oligotrophic marine system. Aquat Microb Ecol 19:205-213

> Helton RR, Liu L, Wommack KE (2006) Assessment of factors influencing direct enumeration of viruses within estuarine sediments. Appl Environ Microbiol 72:4767-4774

Hennes KP, Suttle CA (1995) Direct counts of viruses in natural waters and laboratory cultures by epifluorescence microscopy. Limnol Oceanogr 40:1050-1055

> Hewson I, Fuhrman JA (2006) Viral impacts upon marine bacterioplankton assemblage structure. J Mar Biol Assoc UK 86:577-589

> Hewson I, Fuhrman JA (2007) Covariation of viral parameters with bacterial assemblage richness and diversity in the water column and sediments. Deep-Sea Res I 54:811-830

Hewson I, Vargo GA, Fuhrman JA (2003) Bacterial diversity in shallow oligotrophic marine benthos and overlying waters: effects of virus infection, containment, and nutrient enrichment. Microb Ecol 46:322-336

> Hopkinson CS Jr, Giblin AE, Garritt RH, Tucker J, Hullar MAJ (1998) Influence of the benthos on growth of planktonic estuarine bacteria. Aquat Microb Ecol 16: 109-118 
Hoppe HG (1993) Use of fluorogenic model substrates for extracellular enzyme activity (EEA) of bacteria. In: Kemp PF, Sherr BF, Sherr EB, Cole JJ (eds) Handbook of methods in aquatic microbial ecology. Lewis Publishers, Boca Raton, FL, p 423-431

Ittekkot V (1982) Variations of dissolved organic matter during a plankton bloom: qualitative aspects, based on sugar and amino acid analyses. Mar Chem 11:143-158

Jackson EF, Jackson CR (2008) Viruses in wetland ecosystems. Freshw Biol 53:1214-1227

Jardillier L, Bettarel Y, Richardot M, Bardot C, Amblard C, Sime-Ngando T, Debroas D (2005) Effects of viruses and predators on prokaryotic community composition. Microb Ecol 50:557-569

Joint I, Henriksen P, Fonnes GA, Bourne D, Thingstad TF, Riemann B (2002) Competition for inorganic nutrients between phytoplankton and bacterioplankton in nutrient manipulated mesocosms. Aquat Microb Ecol 29:145-159

Joux F, Servais P, Naudin JJ, Lebaron P, Oriol R, Courties C (2005) Distribution of picophytoplankton and bacterioplankton along a river plume gradient in the Mediterranean Sea. Vie Milieu 55:197-208

> Jumars PA, Penry DL, Baross JA, Perry MJ, Frost BW (1989) Closing the microbial loop: dissolved carbon pathway to heterotrophic bacteria from incomplete ingestion, digestion and absorption in animals. Deep-Sea Res 36:483-495

Jürgens K, Matz C (2002) Predation as a shaping force for the phenotypic and genotypic composition of planktonic bacteria. Antonie van Leeuwenhoek 81:413-434

> Jürgens K, Pernthaler J, Schalla S, Amann R (1999) Morphological and compositional changes in a planktonic bacterial community in response to enhanced protozoan grazing. Appl Environ Microbiol 65:1241-1250

Karner M, Herndl GJ (1992) Extracellular enzymatic activity and secondary production in free-living and marine-snowassociated bacteria. Mar Biol 113:341-347

Kent AD, Yannarell AC, Rusak JA, Triplett EW, McMahon KD (2007) Synchrony in aquatic microbial community dynamiCs. ISME J 1:38-47

Kirchman DL (1994) The uptake of inorganic nutrients by heterotrophic bacteria. Microb Ecol 28:255-271

Kirchman DL, Dittel AI, Findlay SEG, Fischer D (2004) Changes in bacterial activity and community structure in response to dissolved organic matter in the Hudson River, New York. Aquat Microb Ecol 35:243-257

Kragh T, Søndergaard M (2004) Production and bioavailability of autochthonous dissolved organic carbon: effects of mesozooplankton. Aquat Microb Ecol 36:61-72

Lancelot C, Billen G (1984) Activity of heterotrophic bacteria and its coupling to primary production during the spring phytoplankton bloom in the southern bight of the North Sea. Limnol Oceanogr 29:721-730

> Langenheder S, Jürgens K (2001) Regulation of bacterial biomass and community structure by metazoan and protozoan predation. Limnol Oceanogr 46:121-134

Larsen A, Castberg T, Sandaa RA, Brussaard CPD and others (2001) Population dynamics and diversity of phytoplankton, bacteria and viruses in a seawater enclosure. Mar Ecol Prog Ser 221:47-57

Legendre L, Rassoulzadegan F (1995) Plankton and nutrient dynamics in marine waters. Ophelia 41:153-172

Lorenzen C (1966) A method for the continuous measurement of in vivo chlorophyll concentration. Deep-Sea Res 13: $223-227$

Maranger R, Bird DF (1995) Viral abundance in aquatic systems: a comparison between marine and fresh waters. Mar Ecol Prog Ser 121:217-226
Maranger R, Bird DF, Juniper SK (1994) Viral and bacterial dynamics in Arctic sea ice during the spring algal bloom near Resolute, N.W.T., Canada. Mar Ecol Prog Ser 111: 121-127

> Marston MF, Sallee JL (2003) Genetic diversity and temporal variation in the cyanophage community infecting marine Synechococcus species in Rhode Island's coastal waters. Appl Environ Microbiol 69:4639-4647

Martinez J, Smith DC, Steward GF, Azam F (1996) Variability in ectohydrolytic enzyme activities of pelagic marine bacteria and its significance for substrate processing in the sea. Aquat Microb Ecol 10:223-230

- Middelboe M (2000) Bacterial growth rate and marine virushost dynamics. Microb Ecol 40:114-124

Middelboe M, Lyck PG (2002) Regeneration of dissolved organic matter by viral lysis in marine microbial communities. Aquat Microb Ecol 27:187-194

> Middelboe M, Riemann L, Steward GF, Hansen V, Nybroe O (2003) Virus-induced transfer of organic carbon between marine bacteria in a model community. Aquat Microb Ecol 33:1-10

> Miki T, Jacquet S (2008) Complex interactions in the microbial world: underexplored key links between viruses, bacteria and protozoan grazers in aquatic environments. Aquat Microb Ecol 51:195-208

Miki T, Jacquet S (2010) Indirect interactions in the microbial world: specificities and similarities to plant-insect systems. Popul Ecol 52:475-483

> Misic C, Fabiano M (2006) Ectoenzymatic activity and its relationship to chlorophyll-a and bacteria in the Gulf of Genoa (Ligurian Sea, NW Mediterranean). J Mar Syst 60:193-206

> Monger BC, Landry MR, Brown SL (1999) Feeding selection of heterotrophic marine nanoflagellates based on the surface hydrophobicity of their picoplankton prey. Limnol Oceanogr 44:1917-1927

> Motegi C, Nagata T, Miki T, Weinbauer MG, Legendre L, Rassoulzadegan F (2009) Viral control of bacterial growth efficiency in marine pelagic environments. Limnol Oceanogr 54:1901-1910

Nagata T (2008) Organic matter-bacteria interactions in seawater. In: Kirchman DL (ed) Microbial ecology of the oceans. Wiley-Liss, New York, NY, p 207-241

Noble RT, Fuhrman JA (1998) Use of SYBR Green I for rapid epifluorescence counts of marine viruses and bacteria. Aquat Microb Ecol 14:113-118

Ory P, Hartmann HJ, Jude F, Dupuy C and others (2010) Pelagic food web patterns: Do they modulate virus and nanoflagellate effects on picoplankton during the phytoplankton spring bloom? Environ Microbiol 12:2755-2772

Parada V, Herndl GJ, Weinbauer MG (2006) Viral burst size of heterotrophic prokaryotes in aquatic systems. J Mar Biol Assoc UK 86:613-621

Polymenakou PN, Pusceddu A, Tselepides A, Polychronaki T and others (2005) Benthic microbial abundance and activities in an intensively trawled ecosystem (Thermaikos Gulf, Aegean Sea). Cont Shelf Res 25:2570-2584

Porter KG, Feig YS (1980) The use of DAPI for identifying and counting aquatic microflora. Limnol Oceanogr 25:943-948

$>$ Pradeep Ram AS, Sime-Ngando T (2008) Functional responses of prokaryotes and viruses to grazer effects and nutrient additions in freshwater microcosms. ISME J 2: 498-509

> Riemann L, Steward GF, Azam F (2000) Dynamics of bacterial community composition and activity during mesocosm diatom bloom. Appl Environ Microbiol 66:578-587

Rivkin RB, Anderson MR (1997) Inorganic nutrient limitation of oceanic bacterioplankton. Limnol Oceanogr 42:730-740 
Sala MM, Arin L, Balagué V, Felipe J, Guadayol O, Vaqué D (2005) Functional diversity of bacterioplankton assemblages in western Antarctic seawaters during late spring. Mar Ecol Prog Ser 292:13-21

Sandaa RA (2008) Burden or benefit? Virus-host interactions in the marine environment. Res Microbiol 159:374-381

Sandaa RA, Gomez-Consarnau L, Pinhassi J, Riemann L and others (2009) Viral control of bacterial biodiversity-evidence from a nutrient-enriched marine mesocosm experiment. Environ Microbiol 11:2585-2597

Sautour B, Castel J (1993) Distribution of zooplankton populations in Marennes-Oléron Bay (France), structure and grazing impact of copepod communities. Oceanol Acta 16: 279-290

Schwalbach MS, Hewson I, Fuhrman JA (2004) Viral effects on bacterial community composition in marine plankton microcosms. Aquat Microb Ecol 34:117-127

Šimek K, Vrba J, Pernthaler J, Posch T, Hartman P, Nedoma J, Psenner R (1997) Morphological and compositional shifts in an experimental bacterial community influenced by protists with contrasting feeding modes. Appl Environ Microbiol 63:587-595

Šimek K, Kojecka P, Nedoma J, Hartman P, Vrba J, Dolan JR (1999) Shifts in bacterial community composition associated with different microzooplankton size fractions in a eutrophic reservoir. Limnol Oceanogr 44: 1634-1644

Šimek K, Pernthaler J, Weinbauer MG, Hornak K and others (2001) Changes in bacterial community composition and dynamics and viral mortality rates associated with enhanced flagellate grazing in mesoeutrophic reservoir. Appl Environ Microbiol 67:2723-2733

Strickland JDH, Parsons TR (1972) A practical handbook of seawater analysis. Bull Fish Res Board Can 167, 311

Struski C (2005) Modélisation des flux de matières dans la baie de Marennes-Oléron: couplage de l'hydrodynamisme, de la production primaire et de la consommation par les huîtres. Thèse de doctorat d'état, Université de La Rochelle, La Rochelle

Suttle CA (2007) Marine viruses-major players in the global ecosystem. Nat Rev Microbiol 5:801-812

Suttle CA, Chan AM (1994) Dynamics and distribution of Cyanophages and their effect on marine Synechococcus spp. Appl Environ Microbiol 60:3167-3174

Suttle CA, Chan AM, Cottrell M (1991) Use of ultrafiltration to isolate viruses from seawater which are pathogens of marine phytoplankton. Appl Environ Microbiol 57: 721-726

Suzuki MT (1999) Effect of protistan bacterivory on coastal bacterioplankton diversity. Aquat Microb Ecol 20:261-272

Teira E, Martinez-Garcia S, Calvo-Diaz A, Moran XAG (2010) Effects of inorganic and organic nutrient inputs on bacterioplankton community composition along a latitudinal transect in the Atlantic Ocean. Aquat Microb Ecol 60: 299-313

Thingstad TF (2000) Elements of a theory for the mechanisms controlling abundance, diversity, and biogeochemical role of lytic bacterial viruses in aquatic systems. Limnol Oceanogr 45:1320-1328

Van Wambeke F (1994) Influence of phytoplankton lysis or grazing on bacterial metabolism and trophic relationships. Microb Ecol 27:143-158

Van Wambeke F, Ghiglione JF, Nedoma J, Mével G, Raim- bault P (2009) Short scale variations in nutrients, ectoenzymatic activities and bottom-up effects on bacterial production and community structure during late summerautumn transition in the open NW Mediterranean Sea. Biogeosciences Discuss 6:687-727

- Wainright SC (1990) Sediment-to-water fluxes of particulate material and microbes by resuspension and their contribution to planktonic food web. Mar Ecol Prog Ser 62:271-281

> Waterbury JB, Valois FW (1993) Resistance to co-occurring phages enables marine Synechococcus communities to coexist with cyanophages abundant in seawater. Appl Environ Microbiol 59:3393-3399

> Weinbauer MG, Rassoulzadegan F (2003) Are viruses driving microbial diversification and diversity? Environ Microbiol $6: 1-11$

> Weinbauer MG, Bettarel Y, Cattaneo R, Luef B and others (2009) Viral ecology of organic and inorganic particles in aquatic systems: avenues for further research. Aquat Microb Ecol 57:321-341

- Wen K, Ortmann AC, Suttle CA (2004) Accurate estimation of viral abundance by epifluorescence microscopy. Appl Environ Microbiol 70:3862-3867

Wilhelm SW, Suttle CA (1999) Viruses and nutrient cycles in the sea. Bioscience 49:781-788

- Winget DM, Wommack KE (2008) Randomly amplified polymorphic DNA PCR as a tool for assessment of marine viral richness. Appl Environ Microbiol 74:2612-2618

Winget D, Williamson KE, Helton RR, Wommack KE (2005) Tangential flow diafiltration: an improved technique for estimation of virioplankton production. Aquat Microb Ecol 41:221-232

> Winter C, Weinbauer MG (2010) Randomly amplified polymorphic DNA reveals tight links between viruses and microbes in the bathypelagic zone of the northwestern Mediterranean Sea. Appl Environ Microbiol 76: 6724-6732

Winter C, Herndl GJ, Weinbauer MG (2004a) Diel cycles in viral infection of bacterioplankton in the North Sea. Aquat Microb Ecol 35:207-216

Winter C, Smit A, Herndl GJ, Weinbauer MG (2004b) Impact of virioplankton on archaeal and bacterial community richness as assessed in seawater batch cultures. Appl Environ Microbiol 70:804-813

Winter C, Bouvier T, Weinbauer MG, Thingstad TF (2010) Trade-offs between competition and defense specialists among unicellular planktonic organisms: the 'killing the winner' hypothesis revisited. Microbiol Mol Biol Rev 74: $42-57$

Wommack KE, Hill RT, Kessel M, Russek-Cohen E (1992) Distribution of viruses in the Chesapeake Bay. Appl Environ Microbiol 58:2965-2970

- Worden AZ, Nolan JK, Palenik B (2004) Assessing the dynamics and ecology of marine picophytoplankton: the importance of the eukaryotic component. Limnol Oceanogr 49: 168-179

Zöllner E, Hoppe HG, Sommer U, Jürgens K (2009) Effect of zooplankton-mediated trophic cascades on marine food web components (bacteria, nanoflagellates, ciliates). Limnol Oceanogr 54:262-275

Zoppini A, Puddu A, Fazi S, Rosati M, Sist P (2005) Extracellular enzyme activity and dynamics of bacterial community in mucilaginous aggregates of the northern Adriatic Sea. Sci Total Environ 353:270-286 